\title{
Altruism, Incomplete Markets, and Tax Reform
}

\author{
Luisa Fuster* $\quad$ Ayşe İmrohoroğlu ${ }^{\dagger} \quad$ Selahattin İmrohoroğlu
}

September 29, 2007

\begin{abstract}
We compute the welfare effects of different revenue-neutral tax reforms that eliminate capital income taxation in a general equilibrium model calibrated to the U.S. economy. We find that the reform with the largest welfare gain is the one that eliminates all income taxation and increases the consumption tax to $35 \%$. In our calibrated dynastic economy, $75 \%$ of the population alive at the time of the reform benefit from it. Altruism plays an important role in this result. Individuals use intervivos transfers and bequests to redistribute the long-run benefits in the form of higher after-tax wages and interest rates that will benefit future generations toward the current generations. Indeed, in a pure life-cycle economy calibrated to the same U.S. observations, we find that the same reform would benefit only $9 \%$ of the population. The increase in the consumption tax at the initial period of the transition hurts all individuals except for the very young workers. Since generations are not linked by private transfers, the efficiency gains of this reform are only enjoyed by generations born in the very far future. A popular tax reform in the pure life-cycle model is one that benefits current generations regardless of the impact on future generations. For instance, the elimination of capital income taxation financed with an increase in the wage tax benefits $63 \%$ of the population living at the time of the reform but decreases welfare in the long-run.
\end{abstract}

\footnotetext{
Abstract

Keywords: Tax reform; Altruism; Overlapping Generations; Heterogeneous agents; Welfare.

JEL Classification: E6; D52; C68; H55

${ }^{*}$ Department of Economics, University of Toronto, 150 St. George Street, Toronto, ON M5S 3G7, Canada. E-mail: luisa.fuster@utoronto.ca

${ }^{\dagger}$ Department of Finance and Business Economics, Marshall School of Business, University of Southern California, Los Angeles CA 90089-1427. E-mail: ayse@marshall.usc.edu

${ }^{\ddagger}$ Department of Finance and Business Economics, Marshall School of Business, University of Southern California, Los Angeles CA 90089-1427. E-mail: selo@marshall.usc.edu
} 


\section{Introduction}

There is a large literature on optimal tax structure following the seminal work by Judd (1985) and Chamley (1986). The main message of this Ramsey approach in the standard one-sector growth model with complete markets is to drive the capital income tax rate to zero in the long run; it is optimal not to distort capital accumulation. When markets are incomplete, however, Aiyagari (1995) finds it optimal to tax capital income which prevents over-accumulation of capital due to self-insurance. In a pure overlapping generations with complete markets, Erosa and Gervais (2002) show that the Ramsey solution calls for nonzero capital income taxation and tax rates that vary over the life cycle to enhance efficiency in the face of age-varying earnings and saving profiles. In overlapping generations and incomplete markets settings, İmrohoroğlu (1998), Garriga (2003), and Conesa, Kitao, and Krueger (2006) also find that it might be optimal to tax capital income.

In the Ramsey literature, the government is typically restricted to linear taxes that are functions of only current observables and it can observe the effort and earnings of the agents. A recent approach to the optimal taxation problem uses a class of dynamic economies with private information and allows the government to design its tax code in a nonlinear or historydependent fashion. Golosov, Kocherlakota, and Tsyvinski (2003), Albanesi and Sleet (2006), and Kocherlakota (2005) explore the nature of constrained Pareto optimal allocations and their implementation in dynamic, informationally-constrained economies.

A related literature tries to quantify the impact of tax reform on the U.S. economy by simulating general equilibrium models with various features. Summers (1981) and Auerbach, Kotlikoff and Skinner (1983) use life cycle models to estimate the impact of tax reform. The seminal work by Auerbach and Kotlikoff (1987) develops a general equilibrium model with overlapping generations and complete markets, and quantitatively explores the welfare effect of various tax reforms. Their base case results indicate significant capital deepening when the tax base is changed from a 15 percent income tax to a 20.1 percent wage tax or a 17.6 percent consumption tax. Using a fictitious tax-transfer authority to compensate welfare losses along the transition to the final steady-state, they find that there is an overall efficiency loss with a switch to wage taxation and an efficiency gain when the income tax is replaced with a consumption tax. ${ }^{1}$ İmrohoroğlu (1998) uses a pure OG model with incomplete markets and finds that a positive capital income tax maximizes long run welfare as the shift in the tax burden from the younger and liquidity constrained years in the life cycle enhances self-insurance against the idiosyncratic shock. In the context of social security reform that alters the tax structure in the economy, De Nardi, İmrohoroğlu, and Sargent (1999) find large long run gains in privatization but substantial losses to the transitional generations, making privatization politically very difficult. Building on the earlier Auerbach and Kotlikoff work, Altig, Auerbach, Kotlikoff, Smetters, and Walliser (2001) obtain a similar result in the context of tax reform in the United States. Despite long run gains in output and 'average' welfare, certain groups experience welfare losses.

This paper examines the welfare impact of various tax reform proposals. Instead of formulating a Ramsey problem, we follow the tradition of Auerbach and Kotlikoff (1987)

\footnotetext{
${ }^{1}$ See their tables 5.7 and 5.8 .
} 
and cast our question taking the actual U.S. government institutions as given. Starting from given initial conditions that represent the current U.S. economy and the tax code, we compute an equilibrium transition to a new balanced growth path, describe the welfare effects, and show the percentage of population for or against tax reform. We ask 'Using a carefully calibrated model based on uninsurable idiosyncratic earnings risk, (i) what are the welfare effects of changing the current U.S. tax code on individuals taking into account the transitional effects, and, (ii) what are the characteristics of the households that benefit or lose from tax reform?' In our setup, there is a realistic pension system with retirement benefits that are partially linked to contributions and financed with a payroll tax that distorts labor supply decisions and may also hurt borrowing constrained individuals. We calibrate the model to the U.S. data and numerically characterize transition paths from the current tax system to a reformed system. All our experiments are revenue-neutral. Starting from the current tax code, we allow for transitions to reformed steady-states in which the capital income taxation or labor income taxation is eliminated, with the lost revenues replaced by a higher labor income or consumption tax.

A contribution of this paper is to provide a framework where the welfare implications of tax reform are examined both in a pure overlapping generations model and a dynastic environment populated with individuals who otherwise face similar uninsurable permanent and temporary income shocks and mortality risk. Our results indicate that there are significant differences in how tax reform will impact different individuals depending on the framework adopted. When altruistic links across generations are allowed to operate, both family members and households that belong to the same dynasty help insure the members of the same household and dynasty against ability, income and mortality shocks. Bequests and inter vivos transfers are used as instruments to provide these insurance demands. A pure life cycle model, however, provides a very different environment as the individuals can only self-insure against these shocks, and furthermore, have no links to any other generation. In addition, they also have a significant desire to save for retirement. These differing motives to save result in quantitatively different responses to tax reform in the two economies.

Computation of the transitional paths help us produce detailed welfare effects on all generations following a reform. In both cases, eliminating the capital income tax by raising the labor income tax hurts the younger generations who may also be facing borrowing constraints. On the other hand, when a higher consumption tax is used to eliminate all of income taxation, long run gains are highest in both models. However, in both cases, the increased consumption tax hurts the retirees the most. In the altruistic model, the family serves as a very effective insurance mechanism and we find that a majority of the individuals are better off transitioning from the benchmark fiscal policy toward the reformed steady-state where there is no income taxation. The dynastic links work as an informal redistribution mechanism to deliver some of the future gains to current generations. In the life cycle model, individuals do not have any generational links and this backward transfer is not possible. As a result, life cycle individuals are worse off when income taxation is eliminated and replaced by a consumption tax.

It is important to note that while the family insurance in the altruistic model might seem extreme at first glance, it delivers empirically plausible wealth transmission statistics. 
For example we find that in the benchmark economy $81.7 \%$ of intervivos transfers are from parents to children. Gale and Scholz (1994) report that in the U.S. about $75 \%$ of transfers involve parents giving to children. Furthermore, the altruistic model generates the ratio of wealth held by 75 and older individuals to average wealth to be 1.76. This ratio for the U.S. economy is about 1.75. The life-cycle model, on the other hand, generates this statistic to be 0.52. These observations suggest that the quantitative implications of the altruistic model may be adequately capturing the extent of family insurance and the saving behavior of the elderly present in the U.S. economy and more accurately than the life-cycle model.

The remainder of the paper is organized as follows: Section 2 describes the model and Section 3 describes the calibration of the benchmark economy. Section 4 presents the results, Section 5 the sensitivity analysis, and Section 6 concludes.

\section{Two Environments}

We examine two models, one in which there are altruistically linked households and the other that is composed of pure life-cycle agents. Some features of the two models are identical, such as technology and fiscal policy, and some features are different such as preferences. Below is a description of the two environments.

\subsection{Technology}

In both environments, there is a representative firm which rents capital, $K$, and hires labor, $N$, to produce a single good using a Cobb-Douglas production function $Y_{t}=K_{t}^{\alpha}\left(A_{t} N_{t}\right)^{1-\alpha}$, where $\alpha \in(0,1)$ is the output share of capital, $Y_{t}$ is output at time $t, K_{t}$ is aggregate capital input at time $t, N_{t}$ is aggregate labor input at time $t$, and $A_{t}$ is an exogenous laboraugmenting technological progress growing at a constant rate $g$. Capital depreciates at a constant rate $\delta \in(0,1)$. Firms maximize profits so that factor prices are set equal to marginal products

$$
\begin{aligned}
\widetilde{r}_{t} & =\alpha K_{t}^{\alpha-1}\left(A_{t} N_{t}\right)^{1-\alpha}, \\
\omega_{t} & =(1-\alpha) K_{t}^{\alpha}\left(A_{t} N_{t}\right)^{-\alpha}
\end{aligned}
$$

\subsection{Social Security and Fiscal Policy}

Both environments have a pay-as-you-go social security system where pension benefits to retired individuals are financed by taxing earnings of the current workers. The payroll tax, $\tau_{s}$, is set to balance the budget of the social security system each period. An individual's pension is a function of that individual's average lifetime earnings via a concave, piecewise linear function. This function captures the progressivity of the U.S. benefit formula and it is described in Section 3. A progressive social security provides insurance against labor income risk. In our economy, the degree of progressivity of social security is counterbalanced by the empirically supported feature that low ability individuals have a shorter life expectancy than that of high ability individuals. In addition, social security provides insurance against longevity risk for which private markets are assumed to be unavailable. 
The government also taxes labor income at the flat rate $\tau_{n}$, capital income at $\tau_{k}$, and consumption at $\tau_{c}$ in order to finance an exogenously given level of government purchases $G$. The labor income tax is set such that the government budget is balanced. ${ }^{2}$ The government budget constraint is given by

$$
G=\tau_{c} C+\tau_{n} \omega N+\tau_{k} r K .
$$

$\tau_{c}, \tau_{n}$ and $\tau_{k}$ denote the consumption, labor income and capital income tax rates, $C, N$, and $K$ are aggregate consumption, labor input in efficiency units, and aggregate capital stock, and $r$ is the return on the capital stock.

\subsection{Demographics and Endowments}

Every period $t$ a generation of individuals is born. They face random lives and some live through the maximum possible age $2 T$. Conditional on survival, an individual's lifetime support overlaps during the first $T$ periods with the lifetime support of his parent, and during the last $T$ periods with the lifetime support of his children. ${ }^{3}$ At any point in time, the economy is populated by $2 T$ overlapping generations of individuals with total measure one.

Individuals are endowed with one unit of time. In each period until they reach the mandatory retirement age of $R$, they supply labor services to the firms.

At birth, each individual receives the realization of a random variable $z \in Z=\{H, L\}$ that determines his permanent lifetime labor ability. In the altruistic model, $z$ is a two-state, first-order Markov process with the transition probability matrix

$$
\Pi\left(z^{\prime}, z\right)=\left[\pi_{i j}\right], \quad i, j \in\{H, L\},
$$

where $\pi_{i j}=\operatorname{Pr}\left\{z^{\prime}=j \mid z=i\right\}, z^{\prime}$ is the labor ability of the new born children and $z$ is the labor ability of his parent. The transition probabilities are consistent with the existence of a unique stationary measure of abilities $\lambda(z)$.

Permanent labor ability shock affects three features of an individual's lifetime opportunities. First, labor ability determines an individual's life expectancy. Let $\psi_{j}(z)$ denote the probability of surviving to age $j+1$ conditional on having survived to age $j$ for an individual with ability $z$ for age $j=1,2, \ldots, 2 T$, where $\psi_{2 T}(z)=0$ and $z \in\{H, L\}$. Second, $z$ determines the individual's (expected) age-efficiency profile $\left\{\varepsilon_{j}(z)\right\}_{j=1}^{2 T}$. If $z=H$, an individual has a higher (expected) labor productivity throughout his life-span than an individual with $z=L$. Third, it affects the stochastic process for the uninsurable idiosyncratic productivity shock individuals face over their working years. In particular, the labor productivity of an

\footnotetext{
${ }^{2}$ In addition, the government collects the asset holdings and capital income left behind by deceased individuals who do not have any descendants or predecessor. These resources are transferred in a lump-sum fashion to the entire population.

${ }^{3}$ It will become clear in the next section that the difference between a dynastic model and a pure-life cycle model will be in the way preferences are structured. In the dynastic model, since parents and children care about each other, there are altruistic transfers between them as well as bequests. In the pure life cycle model there are no such transfers or bequests.
} 
individual of ability $z$ and age $j$ is $\varepsilon_{j}(z) e^{u_{j}(z)}$ where $u_{j}(z)$ follows a different $A R(1)$ process depending on the realization of $z$. In the calibration section we explain how these two random variables are distributed in more detail. We assume that there are no private insurance markets in the economy to diversify the risk of living too long and the risk of permanent and temporary labor income shocks.

The size of cohort 1 with ability $z$, relative to that of cohort $(T+1)$ is $\mu_{1}(z)=\lambda(z)(1+n)^{T}$ where $(1+n)^{T}$ is the number of children per parent and $\lambda(z)$ is the measure of newborn individuals with ability $z$. The relative sizes of the other generations are obtained recursively as follows:

$$
\mu_{i+1}(z)=\frac{\psi_{i}(z) \mu_{i}(z)}{(1+n)}, \quad i=1, \ldots, 2 T-1 .
$$

The population growth rate, $n$, and conditional survival probabilities, $\psi_{i}(z)$, are taken as time-invariant which makes the cohort shares stationary.

\subsection{Dynastic Model: Households' Decision Problem}

In the dynastic model, individuals derive utility from their own lifetime consumption and leisure, and from the lifetime utility of their predecessors and descendants. We assume that parents and children have the same objective function during the periods when their lives overlap (as in Laitner (1992)). Because of this commonality of interests, during the periods when their lives overlap the parent and the children constitute a single decision unit by pooling their resources. This decision unit is called a household and is constituted by an adult male, the "parent", of age $T+1$, and his $m=(1+n)^{T}$ adult children of age 1 . A household lasts $T$ periods or until the parent and the children have died. ${ }^{4} \mathrm{~A}$ dynasty is a sequence of households that belong to the same family line. If the children survive to age $T+1$, each of them becomes a parent in the next-generation household of the dynasty. Otherwise, the family line is broken, and this particular dynasty is over. Every period some dynasties disappear since there are individuals who do not reach age $T+1$. These dynasties are replaced by new dynasties in order to maintain a stationary demographic structure. ${ }^{5}$

Households are heterogeneous with respect to their asset holdings, age, abilities, and their composition. The composition of a household changes when either the parent or his $m$ children die. Since the life-span shock that affects each of the children are perfectly correlated, there are three types of households. Households of type- 1 are those where the parent has died. Households of type- 2 are those where the $m$ children have died. Households of type- 3 are those where both the parent and the children are still alive.

The budget constraint facing an age- $j$ household, where $j=1,2, \ldots, T$ is the age of the

\footnotetext{
${ }^{4}$ In a given household, all children are born at the same period and all of them die at the same period. Children in a given household are identical regarding their labor abilities and vector of conditional survival probabilities.

${ }^{5} \mathrm{~A}$ new dynasty begins with an individual of age 1 that holds zero assets. Since mortality rates are higher for low ability individuals, the number of new dynasties of low ability is higher than the number of dynasties of high ability.
} 
youngest member(s), is given by

$$
\begin{aligned}
{\left[\phi_{s}(h) c_{s, j}+\phi_{f}(h) c_{f, j}\right]\left(1+\tau_{c}\right)+(1+g) a_{j}=} & {\left[1+r\left(1-\tau_{k}\right)\right] a_{j-1} } \\
& +e_{j}\left(h, \bar{e}_{f}, z_{f}, z_{s}, u_{s}, u_{f}\right)+\left[\phi_{s}(h)+\phi_{f}(h)\right] \xi
\end{aligned}
$$

where $\phi_{s}$ is an indicator function which takes the value $m$ if the children are alive and 0 otherwise, while $\phi_{f}$ is an indicator function that takes the value unity if the parent is alive and 0 otherwise; $h \in\{1,2,3\}$ is an indicator of household composition, $r$ is the interest rate $r=\widetilde{r}-\delta, e_{j}\left(h, \bar{e}_{f}, z_{f}, z_{s}, u_{f}, u_{s}\right)$ denotes the after tax earnings which we describe below, $c_{s, j}$ and $c_{f, j}$ are the consumption of the child and the parent, $a_{j}$ denotes the asset holdings to be carried over to age $j+1, \xi$ is a lump sum redistribution of accidental bequests left behind by single individual households and confiscated by the government. Consumption, asset holdings, lump-sum transfers, and earnings are transformed to eliminate the effects of labor augmenting, exogenous productivity growth. In particular, we have normalized those variables by the level of the technology, $A_{t}$, at any period $t .^{6}$

The function $e_{j}\left(h, \bar{e}_{f}, z_{f}, z_{s}, u_{f}, u_{s}\right)$ gives the net of tax earnings of an age- $j$ household of demographic type $h$, parent's average lifetime earnings $\left(\bar{e}_{f}\right)$, and with permanent abilities $z_{f}$ of the parent and $z_{s}$ of the child and realizations of the productivity shock $u_{f}$ for the parent and $u_{s}$ for the child:

$e_{j}\left(h, \bar{e}_{f}, z_{f}, z_{s}, u_{f}, u_{s}\right)=\left\{\begin{array}{l}\phi_{s}(h) \omega\left(1-\tau_{s}-\tau_{n}\right) \varepsilon_{j}\left(z_{s}\right) e^{u_{s}}\left(1-\ell_{s, j}\right)+\phi_{f}(h) B_{j+T}\left(\bar{e}_{f}\right) \text { if } j \geq R-T, \\ \phi_{s}(h) \omega\left(1-\tau_{s}-\tau_{n}\right) \varepsilon_{j}\left(z_{s}\right) e^{u_{s}}\left(1-\ell_{s, j}\right)+ \\ \phi_{f}(h) \omega\left(1-\tau_{s}-\tau_{n}\right) \varepsilon_{j+T}\left(z_{f}\right) e^{u_{f}}\left(1-\ell_{f, j}\right), \quad \text { otherwise }\end{array}\right.$

where $\ell_{s, j}$ and $\ell_{f, j}$ are the leisure of the child and the parent, and $\tau_{s}$ is the social security tax rate. $B_{j+T}\left(\bar{e}_{f}\right)$ denotes the pension at age $j+T$ of which is a function of the parent's average lifetime earnings $\left(\bar{e}_{f}\right) \cdot{ }^{7}$ An individual's pension remains constant during retirement while technology grows at the rate $g$. Thus, the pension per effective labor decreases during retirement at rate $g$. In other words, the retirement benefits of successive cohorts increase at the rate $g$.

For $j=T$, the budget constraint of the household is given by

$$
\begin{aligned}
& {\left[\phi_{s}(h) c_{s, T}+\phi_{f}(h) c_{f, T}\right]\left(1+\tau_{c}\right)+(1+n)^{T}(1+g) a_{T} } \\
= & {\left[1+r\left(1-\tau_{k}\right)\right] a_{T-1}+e_{T}\left(h, \bar{e}_{f}, z_{f}, z_{s}, u_{s}, u_{f}\right)+\left[\phi_{s}(h)+\phi_{f}(h)\right] \xi . }
\end{aligned}
$$

If the children survive to age $T+1,(1+n)^{T}$ new households are constituted in the dynasty and each of them will hold $a_{T}$ assets. If the children do not survive to age $T+1$, the family line breaks.

It is assumed that households face borrowing constraints and cannot hold negative assets at any age: $a_{j} \geq 0, \forall j$.

\footnotetext{
${ }^{6}$ For the sake of clarity, we do not introduce time subscripts although we compute both steady-states and transitional paths across steady-states.

${ }^{7}$ When the age of the son is $j$, the age of the father is $j+T$.
} 
The economic problem of a household is to choose a sequence of consumption, leisure, and asset holdings given a set of fiscal parameters and prices. ${ }^{8}$ The state of a household is given by the age $j$, the assets $a$, the demographic type $h$, permanent abilities of parent and children, $z_{f}, z_{s}$, the realizations of the labor productivity shock for parent, $u_{f}$, and children, $u_{s}$, and the average lifetime earnings of the members of the household $\bar{e}_{f}, \bar{e}_{s}$. The last two variables are part of the state of the household because an individual's pension is a function of the individual's average lifetime earnings. We denote by $V_{j}\left(a, h, \bar{e}_{f}, \bar{e}_{s}, z_{f}, z_{s}, u_{f}, u_{s}\right)$ the steady state maximized value of expected, discounted lifetime utility of an age- $j$ household with the state vector $x=\left(a, h, \bar{e}_{f}, \bar{e}_{s}, z_{f}, z_{s}, u_{f}, u_{s}\right)$. For a household of age $j \leq T$,

$$
\begin{aligned}
V_{j}(x)= & \max _{\left\{c_{s}, c_{f}, l_{s}, l_{f}, a^{\prime}\right\}}\left\{\left[\phi_{s}(h) u\left(c_{s, j}, \ell_{s, j}\right)+\phi_{f}(h) u\left(c_{f, j}, \ell_{f, j}\right)\right]+\beta \widetilde{V}_{j+1}\left(a^{\prime}, h, \bar{e}_{f}^{\prime}, \bar{e}_{s}^{\prime}, z_{f}, z_{s}, u_{f}, u_{s}\right)\right\} \\
& \text { subject to }(2.3)-(2.5), a_{j} \geq 0, \\
\bar{e}_{f}^{\prime}= & {\left[(T+j-1) \bar{e}_{f}+\omega \varepsilon_{j}\left(z_{f}\right) e^{u_{f}}\left(1-\ell_{f, j}\right)\right] /(T+j) \text { and } } \\
\bar{e}_{s}^{\prime}= & {\left[(j-1) \bar{e}_{s}+\omega \varepsilon_{j}\left(z_{s}\right) e^{u_{s}}\left(1-\ell_{s, j}\right)\right] / j }
\end{aligned}
$$

where

$$
\begin{aligned}
& \widetilde{V}_{j+1}\left(a^{\prime}, h, \bar{e}_{f}^{\prime}, \bar{e}_{s}^{\prime}, z_{f}, z_{s}, u_{f}, u_{s}\right) \\
= & \begin{cases}\sum_{h^{\prime}=1}^{3} \chi_{j}\left(h, h^{\prime} ; z_{f}, z_{s}\right) E_{\left\{u_{f}^{\prime}, u_{s}^{\prime} / u_{f}, u_{s}\right\}} V_{j+1}\left(a^{\prime}, h^{\prime}, \bar{e}_{f}^{\prime}, \bar{e}_{s}^{\prime}, z_{f}, z_{s}, u_{f}^{\prime}, u_{s}^{\prime}\right) & \text { for } j<T, \\
\psi_{T}\left(z_{s}\right)(1+n)^{T} E_{\left\{z_{s}^{\prime}, u_{f}^{\prime}, u_{s}^{\prime} / z_{s}, u_{s}\right\}} V_{1}\left(a^{\prime}, 3, \bar{e}_{s}^{\prime}, 0, z_{s}, z_{s}^{\prime}, u_{f}^{\prime}, u_{s}^{\prime}\right) & \text { for } j=T,\end{cases}
\end{aligned}
$$

$\chi_{j}\left(h, h^{\prime} ; z_{f}, z_{s}\right)$ is the probability that a household of age $j$ and type $h$ becomes type $h^{\prime}$ the next period given that the parent is of ability $z_{f}$ and the children of ability $z_{s} .{ }^{9}$ Note that a household of age $T$ faces four shocks. First, there is a permanent life-span shock that affects the youngest members of the household. Second, there is a permanent ability shock that affects the new generation of the dynasty. The youngest members will survive with probability $\psi_{T}\left(z_{s}\right)$ and constitute $(1+n)^{T}$ new households; by construction these are type 3 households. The permanent ability of the new generation of the dynasty is correlated with the ability of the parent; that is, $z_{s}^{\prime}$ is correlated with $z_{s}$. A third shock affects the labor productivity of the new parent. The labor productivity of the (new) parent is denoted by $u_{f}^{\prime}$ and is correlated with the previous period realization $u_{s}$ (the individual was a 'child' in the previous household). A fourth shock affects the labor productivity of the new member of the dynasty. The (new) children draw a labor productivity shock $u_{s}^{\prime}$ from its invariant distribution.

\footnotetext{
${ }^{8}$ We assume a CRRA utility function which is consistent with the existence of a stationary equilibrium.

${ }^{9}$ This transition probability matrix is a function of the age of the household and of the abilities of the parent and the child, and is given by

$$
\left[\chi_{j}\left(h, h^{\prime} ; z, z^{\prime}\right)\right]_{h, h^{\prime} \in\{1,2,3\}}=\left[\begin{array}{ccc}
\psi_{j}\left(z^{\prime}\right) & 0 & 0 \\
0 & \psi_{j+T}(z) & 0 \\
\psi_{j}\left(z^{\prime}\right)\left(1-\psi_{j+T}(z)\right) & \left(1-\psi_{j}\left(z^{\prime}\right)\right) \psi_{j+T}(z) & \psi_{j}\left(z^{\prime}\right) \psi_{j+T}(z)
\end{array}\right] .
$$
}




\subsection{Pure Life-cycle Model: Households' Decision Problem}

In the pure life-cycle model, individuals obtain utility from their lifetime consumption and leisure and they do not care about their descendants and predecessors. The expected utility of an individual of age $j$ is

$$
\sum_{i=j}^{2 T} \beta^{i-j}\left[\prod_{k=j}^{i} \psi_{k}(z)\right] u\left(c_{i}, \ell_{i}\right)
$$

where $c$ denotes consumption per effective labor and $\ell$ denotes leisure time as in the dynastic model. The budget constraint for an individual of age $j$ is

$$
\left(1+\tau_{c}\right) c_{j}+(1+g) a_{j}=\left[1+r\left(1-\tau_{k}\right)\right] a_{j-1}+e_{j}(\bar{e}, z, u)+\xi
$$

where asset holdings at the beginning of age $j$ are given by $a_{j-1}$ and $e_{j}(\bar{e}, z, u)$ gives the net of tax earnings of an age- $j$ individual with average lifetime earnings $\bar{e}$, permanent ability $z$, and a realization of the productivity shock $u$,

$$
e_{j}(\bar{e}, z, u)=\left\{\begin{array}{cr}
B_{j}(\bar{e}) & \text { if } j \geq R \\
\omega\left(1-\tau_{s}-\tau_{n}\right) \varepsilon_{j}(z) e^{u}\left(1-\ell_{j}\right) & \text { otherwise }
\end{array}\right.
$$

Each individual receives a lump-sum amount $\xi$ which is the sum of accidental bequests left behind by individuals who die prior to age $2 T$ and which are confiscated by the government. Similar to the dynastic model, we assume that there is no borrowing: $a_{j} \geq 0$, all $j$ with $a_{1}=$ $a_{2 T}=0$. Consumption, asset holdings, lump-sum transfers, and earnings are transformed to eliminate the effects of exogenous labor augmenting productivity growth. In particular, we have normalized those variables by the level of the technology, $A_{t}$, at any period $t$.

The economic problem of a household is to choose a sequence of consumption, leisure, and asset holdings given a set of fiscal parameters and given prices. The state of a household is given by the age $j$, the assets $a$, its permanent labor productivity $z$, its age-to-age uninsurable idiosyncratic uncertainty $u$, and the average lifetime earnings of the individual that affects pension payments, $\bar{e}$ (and hence all decisions prior to retirement). We denote by $W_{j}(a, \bar{e}, z, u)$ the steady state maximized value of expected, discounted lifetime utility of an age- $j$ household with the state vector $x=(a, \bar{e}, z, u)$ :

$$
\begin{aligned}
W_{j}(x)= & \max _{\left\{c, \ell, a^{\prime}\right\}}\left\{u(c, \ell)+\beta \widetilde{W}_{j+1}\left(a^{\prime}, \bar{e}^{\prime}, z, u\right)\right\} \\
& \text { subject to } 2.8, a^{\prime} \geq 0, \\
\bar{e}^{\prime}= & {\left[(j-1) \bar{e}+\omega \varepsilon_{j}(z) e^{u}\left(1-\ell_{j}\right)\right] / j, \text { for } j<R } \\
\bar{e}^{\prime}= & \bar{e} \text { for } \mathrm{j} \geq R .
\end{aligned}
$$

where

$$
\widetilde{W}_{j+1}\left(a^{\prime}, \bar{e}^{\prime}, z, u\right)= \begin{cases}\psi_{j}(z) E_{u^{\prime} / u} W_{j+1}\left(a^{\prime}, \bar{e}^{\prime}, z, u^{\prime}\right) & \text { for } j<2 T \\ 0 & \text { for } j=2 T .\end{cases}
$$




\subsection{Stationary Equilibrium and the Transition}

The main purpose of this paper is to examine the welfare implications of various tax reforms. This necessitates the computation of the steady states (initial and the final under different reforms) and the transitional path to the new steady state. Below we will give a brief description of the stationary recursive competitive equilibrium for the altruistic model. ${ }^{10}$ The definition of a stationary competitive equilibrium for the life-cycle model is very similar.

Given a fiscal policy $\left\{G, B, \tau_{k}, \tau_{n}, \tau_{s}, \tau_{c}\right\}$, a stationary recursive competitive equilibrium is a set of value functions $\left\{V_{j}(x)\right\}_{j=1}^{T}$, households' decision rules

$\left\{c_{s, j}(x), c_{f, j}(x), \ell_{s, j}(x), \ell_{f, j}(x), a_{j}(x)\right\}_{j=1}^{T}$, time-invariant measures of households $\left\{X_{j}(x)\right\}_{j=1}^{T}$, with the state vector $x=\left(a, h, \bar{e}_{f}, \bar{e}_{s}, z_{f}, z_{s}\right)$, relative prices of labor and capital $\{\omega, \widetilde{r}\}$, and a lump sum transfer of unintended bequests $\xi$,such that the following conditions are satisfied:

1. Given fiscal policy, factor prices, and lump-sum transfers, households' decision rules solve households' decision problems (2.9).

2. Factor prices are competitive.

3. Aggregate capital stock, labor input and consumption are weighted sums of individual asset holdings, labor supply and consumption choices.

4. Government's budget and the budget of the social security system are balanced.

5. Final goods and factor markets clear.

\section{Calibration of the Two Models}

All parameter values are common to the two models except for two preference parameters and a fiscal policy parameter. In what follows we describe the calibration procedure for the two models.

\subsection{Demographics}

We assume that individuals are born when they are 20 years old and live to be at most 90 years old. If they survive, they retire from the labor market at the age of 65 . Also conditional on survival, individuals' fertile lifetimes conclude when they are 35 years old. At this time they have $m$ children. If individuals reach the age of 55 , they form a household with their $m=1.52$ children. For computational reasons, a model period is five years. These assumptions imply the following parameter values for the model: $T=7$ and $R=10$. When children reach the model age 1 (real time age 20), the parent's age is the model age of 8 (real time age 55) and this household starts making joint decisions. ${ }^{11}$ When the child is 3 periods old (real time age 30), the parent who is at the model age of 10 (real time age 65) retires.

\footnotetext{
${ }^{10}$ For a more detailed description see Fuster, İmrohoroğlu, and İmrohoroğlu (2007).

${ }^{11}$ Note that the children are born when the parent is 35 years old, but the joint decision making only starts after the children reach the age of 20 and start working.
} 
Although the model period is five years, in what follows we express flow variables as rates per year. The population growth rate is constant and consistent with the average annual population growth rate of the U.S. economy, that is, $n=0.012$.

\subsection{Preferences and Technology}

The period utility function is assumed to be

$$
u(c, \ell)=\frac{\left(c^{1-\nu} \ell^{\nu}\right)^{1-\gamma}-1}{1-\gamma}
$$

We choose a value for the intensity of leisure in the utility function such that the average fraction of discretionary time spent on market work is 0.33 . This procedure implies a value for $\nu$ of 0.63 for the dynastic model and 0.69 for the pure life-cycle model. We assume $\gamma=4$ which implies an elasticity of intertemporal substitution of consumption $(1-(1-\nu)(1-\gamma))^{-1}$ of 0.47 for the dynastic model and of 0.52 for the pure life-cycle model which are in the range of estimates (see Auerbach and Kotlikoff (1987)). For both models. the Frisch elasticities of labor supply implied are close to 1.0 which is in the middle of the range of recent econometric estimates. $^{12}$

The exogenous productivity growth rate is taken as $g=1.4 \%$, which is close to the postwar annual average in the U.S. Following İmrohoroğlu, İmrohoroğlu and Joines (1999), the income share of capital, $\alpha$, is taken as 0.31 . The depreciation rate $\delta$ is given by

$$
\delta=\frac{I / Y}{K / Y}-g-n-g n,
$$

where we target an investment-output ratio equal to $21 \%$ and a capital-output ratio of 3.0, yielding $\delta=0.044$. The subjective discount factor, $\widetilde{\beta}$, is chosen so that the economy at the initial steady state produces a capital-output ratio of 3.0. This procedure yields a $\widetilde{\beta}$ of 0.99 for the dynastic model and of 1.038 for the pure life-cycle model. ${ }^{13}$

\subsection{Labor Productivity Shocks}

We assume that the efficiency units of labor of an individual of age $j$ depends on his ability $z$ and the realization of the idiosyncratic shock $u$. In particular, the individual's labor productivity at age $j$ is $\varepsilon_{j}(z) e^{u_{j}(z)}$ where $\varepsilon_{j}(z)$ denotes the mean efficiency units of labor of an age- $j$ individual of ability $z$. We assume that the shock $u$ follows an $A R(1)$ process and that this process is specific for the ability type of the individual, that is $u_{j}(z)=\rho(z) u_{j-1}(z)+\eta_{j}(z)$, and $\eta_{j}(z) \sim N\left(0, \sigma_{\eta_{z}}^{2}\right)$.

We calibrate the profiles of mean efficiency units of labor for high and low ability individuals, $\varepsilon_{j}(z)$, to match the average profiles of efficiency units of labor of college and non-college graduate males, respectively. We construct these indices using data on earnings from the Bureau of the Census (1991).

\footnotetext{
${ }^{12}$ For a summary of the recent literature on the Frisch elasticity of labor supply, see Fuster, İmrohoroğlu, and İmrohoroğlu (2007).

${ }^{13}$ The growth-adjusted discount factor in equation $(2.9)$ is $\beta=\widetilde{\beta}(1+g)^{(1-\nu)(1-\gamma)}$.
} 
We also have to calibrate the parameters $\rho(z)$ and $\sigma_{\eta_{z}}^{2}$ which characterize the $A R(1)$ processes $u_{j}(z)$, for college and non-college graduate workers. We pick the values for these four parameters that match the estimates of Güvenen (2005) for the U.S. economy $(\rho(H)=$ 0.805 and $\sigma_{\eta_{H}}^{2}=0.025$ for college graduates and $\rho(L)=0.829$ and $\sigma_{\eta_{L}}^{2}=0.022$ for noncollege graduates). ${ }^{14}$ We approximate the autoregressive process for $u$ with a two-state first order Markov chain that matches the above values of $\rho$ and $\sigma_{\eta}^{2}$. The transition probability matrices (for the five-year processes) are

$$
\left(\begin{array}{ll}
0.7534 & 0.2465 \\
0.2465 & 0.7534
\end{array}\right) \text { for college and }\left(\begin{array}{ll}
0.776 & 0.224 \\
0.224 & 0.776
\end{array}\right) \text { for non-college. }
$$

The support for $u$ is $(-0.227,0.227)$ for college graduates and $(-0.231,0.231)$ for non-college graduates.

In the altruistic model, the ability $z$ (college or non-college education) follows a first order Markov chain. We choose the values for the transition probabilities characterizing such process so that our benchmark economy matches two observations. First, the proportion of full-time male workers that were college graduates in 1991 was $28 \%$ (see Bureau of the Census (1991), pg. 145). Second, the correlation between the wages of parents and children is 0.4 according to the estimates by Solon (1992). These observations imply for this model that $\pi_{H H}=0.57$ and $\pi_{L L}=0.83$. In the life-cycle model, individuals are born as a collegegraduate $(28 \%)$ or a non-college graduate $(72 \%)$.

Labor ability determines both the lifetime productivity of the individuals and the vector of conditional survival probabilities. We obtain these probabilities for college and non-college graduate males in the U.S. economy from Elo and Preston (1996) who document that lifetime expectancy at the real age of 20 is 5 years longer for a college graduate than for non-college graduate.

\subsection{Social Security and Taxation}

In the U.S. economy, retirement benefits depend on individuals' average lifetime earnings, $\bar{e}$, via a concave, piecewise linear function. The marginal replacement rate decreases with average lifetime earnings indexed to productivity growth. It is equal to 0.9 for earnings lower than $20 \%$ of the economy's average earnings. Above this limit and below $125 \%$ of the economy's average earnings the marginal replacement rate decreases to 0.33 . For income within $125 \%$ and $246 \%$ of the economy's average earnings the marginal replacement rate is 0.15 . Additional income above $246 \%$ of the economy's average earnings does not provide any additional pension payment.

In the benchmark economy, we set the government purchases of goods and services $(G)$ equal to $21.5 \%$ of output and keep $G$ constant across steady states so that our tax reform experiments are revenue neutral, which is standard practice in this literature. We assume a

\footnotetext{
${ }^{14}$ Since Güvenen (2005) estimates an annual process, we compute the values of $\rho$ and $\sigma$ for a five year process which are consistent with the estimates of Güvenen (2005). The parameter values for our five year process are $\sigma_{\eta H}^{2}(H)=0.03835$ and $\rho(H)=0.5069$ for college graduates and $\sigma_{\eta_{L}}^{2}=0.037108$ and $\rho(L)=0.552$ for non-college graduates.
} 
consumption tax rate of $5.5 \%$ and a capital income tax rate of $35 \%$. The labor income tax is set such that the government budget balances which implies a tax rate equal to 0.17 at the benchmark economy in both models. ${ }^{15}$ The following table summarizes all the parameters used in the initial steady state. ${ }^{16}$

\begin{tabular}{|c|c|c|c|c|}
\hline \multicolumn{5}{|c|}{ Table 1: List of Parameters } \\
\hline \multicolumn{5}{|c|}{ Population } \\
\hline \multicolumn{5}{|c|}{ Dynastic Life-cycle } \\
\hline $2 T$ & $=$ & & 14 & Maximum lifetime (90 years) \\
\hline$R$ & $=$ & & 10 & Retirement age ( 65 years) \\
\hline$n$ & $=$ & & $1.2 \%$ & Annual population growth rate. \\
\hline \multicolumn{5}{|c|}{ Preferences } \\
\hline$\gamma$ & $=$ & & 4 & \\
\hline$\nu$ & $=$ & 0.63 & 0.69 & Intensity of leisure in utility \\
\hline$\widetilde{\beta}$ & $=$ & 0.99 & 1.038 & Annual subjective discount factor. \\
\hline \multicolumn{5}{|c|}{ Technology } \\
\hline$g$ & $=$ & & 0.014 & Annual rate of growth of technology \\
\hline$\alpha$ & $=$ & & 0.31 & Capital share of GNP. \\
\hline$\delta$ & $=$ & & 0.044 & Annual depreciation rate. \\
\hline$\lambda(H)$ & $=$ & & 0.28 & Measure of individuals with high ability. \\
\hline$\pi_{L L}=0.83$ & & & $H_{H}=0.57$ & Transition probability matrix of abilities. \\
\hline$\rho_{L}=0.829$ & & & $o_{H}=0.805$ & Correlation coefficient in AR process for $u$ \\
\hline$\sigma_{\eta}^{2}(L)=0.022$ & & & $H)=0.025$ & Variance of innovations in AR process for $u$ \\
\hline \multicolumn{5}{|c|}{ Fiscal Policy } \\
\hline$\tau_{k}$ & $=$ & & 0.35 & Capital income tax rate \\
\hline$\tau_{c}$ & $=$ & & 0.055 & Consumption tax rate \\
\hline$G$ & $=$ & 0.65 & 0.60 & Government purchases \\
\hline
\end{tabular}

Individuals in the altruistic and life-cycle environments face identical or very similar technology, demographics and policy parameters. The only essential difference in the calibration across the two models is the subjective discount factor, which is considerably higher in the life-cycle model in order to generate sufficient saving to hit our capital-output ratio target of 3.0. In the section on sensitivity, we will explore the quantitative impact of a different calibration strategy that will yield a lower subjective discount rate in the life-cycle model.

\footnotetext{
${ }^{15}$ We abstract from the progressivity of the U.S. income tax, which is recenly studied by Coronado, Fullerton, and Glass (2000), Erosa and Koreshkova (2006), and Conesa and Krueger (2006), among others.

${ }^{16}$ The benchmark economy generates a significant amount of wealth inequality. The Gini coefficient for wealth distribution in the model is 0.75 while it is 0.78 in the U.S. economy.

For recent work on a quantitative theory of wealth distribution, see Krusell and Smith (1998), Castañeda, Díaz-Giménez, and Ríos-Rull (2003), and De Nardi (2004).
} 


\section{Quantitative Findings}

In this section, we will report the results from tax reform simulations in both the altruistic and the pure life-cycle models. Although the two models share important precautionary saving motives against the uninsurable income risk and mortality risk that are calibrated identically, they differ significantly in two risk-sharing and saving aspects. In the altruistic model, there is perfect family insurance and in households with both parents and children alive, there is a perfect sharing of the differences in tax incidences such as those from a consumption tax that largely falls on the retirees and wage tax which acts on workers. While individuals save for their retirement in the life cycle model, they save to leave bequests and to give intervivos transfers in the altruistic model. As a result, the same fiscal reform may deliver different quantitative responses from these two models. ${ }^{17}$

Indeed our findings indicate that in the altruistic model, the family serves as a very effective insurance mechanism where the dynastic links work as an informal redistribution mechanism to deliver some of the future gains to current generations. In the life cycle model, individuals do not have any generational links and this backward transfer is not possible. As a result, life cycle individuals are worse off in reforms where most of the gains are realized in the future.

Admittedly, the altruistic model is based upon very strong assumptions. Members of the dynasty are fully altruistic about each other and distribute resources across generations efficiently. Therefore one might expect that bequests and intervivos transfers are going to be exaggerated in this framework. To see if this concern is quantitatively justified, we calculate the model generated intervivos transfers and wealth held by the elderly and check them against their counterparts from the U.S. economy. Using data from the Survey of Consumer Finances for 1983-1985, Gale and Scholz (1994) find that. about $75 \%$ of transfers involve parents giving to children. In our altruistic model we find that $81.7 \%$ of intervivos transfers are from parents to children. Furthermore, according to the Statistical Abstract of the United States: 2006 the ratio of wealth held by 75 and older Americans to average wealth is about $1.75^{18}$ The altruistic model generates this ratio to be 1.76 while in the life-cycle model it is equal to 0.52 . These two observations suggest that while the family insurance in the altruistic model might seem extreme at first glance, it delivers empirically plausible wealth transmission statistics.

Next, we will describe the long run impact of tax reform in the two models and compute the equilibrium transition path to the final steady-state and present the welfare effects of tax reform in the these models.

\footnotetext{
${ }^{17}$ Reforming social security in a pure life cycle model typically yields much larger steady-state gains in the capital stock as individuals increase their private saving to support old age consumption. In an altruistic model, however, the response is usually much smaller quantitatively. See Fuster (1999), Fuster, İmrohoroğlu, and İmrohoroğlu (2003), and Fuster, İmrohoroğlu, and İmrohoroğlu (2007).

${ }^{18}$ These wealth ratios are computed using data from the Survey of Consumer Finances (table 702).
} 


\subsection{Long Run Effects of Tax Reform}

Altruistic Model Table 2 shows the long-run consequences of three tax reforms and an elimination of both social security and capital income taxation, compared to our benchmark economy with social security, consumption, and capital and labor income taxation at the indicated rates. The levels of capital stock, $K$, and labor input, $N$, are normalized to 100 . Aggregate output and consumption are not reported but both go in the same direction with $K$. The first tax reform eliminates the tax on capital income but raises the wage tax rate to leave government revenues unchanged. This raises the tax on labor income from $17.3 \%$ in the benchmark economy to $24.7 \%$. In the second reform, a higher consumption tax is used to make up the lost tax revenues from the elimination of capital income taxation. In the third reform, all income is tax free; a higher consumption tax is used. The last row presents the steady-state in which both capital income taxation and the unfunded social security system are eliminated.

Table 2: Long Run Effects of Tax Reform in the Altruistic Model

\begin{tabular}{rrrrrrrrrr}
\hline \hline \multicolumn{1}{c}{$\tau_{k}$} & \multicolumn{1}{c}{$\tau_{n}$} & \multicolumn{1}{c}{$\tau_{c}$} & \multicolumn{1}{c}{$\tau_{s}$} & $\tau_{\text {eff }}$ & \multicolumn{1}{c}{$K$} & \multicolumn{1}{c}{$N$} & $r\left(1-\tau_{k}\right)$ & $\omega\left(1-\tau_{\text {eff }}\right)$ & $C V$ in $C$ \\
\hline $35 \%$ & $17.3 \%$ & $5.5 \%$ & $10.3 \%$ & $31.4 \%$ & 100.0 & 100.0 & 3.6 & 0.38 & 1.000 \\
0 & $24.7 \%$ & $5.5 \%$ & $10.2 \%$ & $38.3 \%$ & 133.1 & 97.1 & 3.7 & 0.38 & 1.035 \\
0 & $17.3 \%$ & $14.0 \%$ & $10.2 \%$ & $36.4 \%$ & 135.8 & 98.5 & 3.7 & 0.39 & 1.040 \\
0 & 0 & $35.4 \%$ & $10.1 \%$ & $33.6 \%$ & 141.5 & 100.9 & 3.6 & 0.41 & 1.050 \\
0 & $17.3 \%$ & $12.1 \%$ & 0 & $26.2 \%$ & 148.4 & 104.9 & 3.5 & 0.45 & 1.060 \\
\hline \hline
\end{tabular}

In all three tax reforms, eliminating the tax on saving encourages faster capital accumulation, at least $33.1 \%$ faster; the significant rise in the after-tax return on capital induces individuals to save more. Since savings are quite interest elastic, the after-tax interest rate does not change much across steady-states. The first two reforms yield a smaller aggregate labor input. There are two important factors affecting the labor supply. First, the after tax wage rate is different across steady states. We report in the table the after tax wage rate using the effective marginal tax rate on labor income, $\tau_{\text {eff }}=\left(\tau_{n}+\tau_{s}+\tau_{c}\right) /\left(1+\tau_{c}\right)$, (see Prescott 2004). This tax rate determines the wedge between the marginal rate of substitution between consumption and leisure and the real wage. In our model, this is an imperfect measure of the distortion on labor because social security benefits are partially linked to contributions. As we go from the first reform to the last, this imperfect measure of the labor distortion decreases which is consistent with the increase in labor supply. Notice also that the after-tax wage rate increases as we move down in the table. Second, the change in the steady state capital stock induces a wealth effect on labor supply. Since the after-tax wage in the first two reforms are similar to the one in the benchmark economy, we conclude that their lower labor supply is due to a wealth effect of their higher capital stock.

The elimination of the capital income tax yields a larger increase in the capital stock when the reform is financed with consumption taxation rather than with labor income taxation. Since labor earnings stop after retirement, consumption taxation, relatively to wage taxation, taxes individuals relatively more when they are old than when they are young. This life-cycle 
effect implies that individuals have stronger incentives to save under consumption taxation and explains why the reform that induces the largest increase in the capital stock is the one that introduces a pure consumption tax. ${ }^{19}$

When we combine the first tax reform with a simultaneous social security reform, the steady-state gains are larger, both in terms of aggregate capital and especially aggregate labor. However, compared to the first tax reform of capital income tax elimination, the added pension reform raises the capital stock only from 133.1 to 148.4, an $11.5 \%$ increase. The increase in the capital stock from the benchmark economy to the first reform is $33.1 \%$, three times as large.

The last column in Table 2 reports the compensating variation in consumption that will make the 'typical' new-born individual indifferent between being born in the benchmark steady-state economy and an alternative steady-state with tax reform. A compensating variation larger than one indicates that the 'typical' new-born individual would prefer to be born in the steady state under the tax reform. We find that the steady-state welfare gains are quite large.

\section{Pure Life-Cycle Model}

\begin{tabular}{rrrrcccccr}
\hline \multicolumn{1}{c}{ Table 3: Long Run Effects of Tax Reform in the Life Cycle Model } \\
\hline \hline \multicolumn{1}{c}{$\tau_{k} \tau_{n}$} & \multicolumn{1}{c}{$\tau_{c}$} & \multicolumn{1}{c}{$\tau_{s}$} & $\tau_{\text {eff }}$ & \multicolumn{1}{c}{$K$} & $N$ & $r\left(1-\tau_{k}\right)$ & $\omega\left(1-\tau_{e f f}\right)$ & $C V$ in $C$ \\
\hline $35 \%$ & $17.7 \%$ & $5.5 \%$ & $9.7 \%$ & $31.2 \%$ & 100.0 & 100.0 & 3.6 & 0.38 & 1.000 \\
0 & $26.7 \%$ & $5.5 \%$ & $9.6 \%$ & $39.6 \%$ & 110.7 & 96.7 & 4.6 & 0.35 & 0.992 \\
0 & $17.7 \%$ & $15.0 \%$ & $9.6 \%$ & $36.8 \%$ & 123.1 & 98.4 & 4.2 & 0.37 & 1.021 \\
0 & 0 & $35.4 \%$ & $9.7 \%$ & $33.3 \%$ & 147.7 & 100.7 & 3.4 & 0.41 & 1.054 \\
0 & $17.7 \%$ & $10.0 \%$ & 0 & $25.2 \%$ & 184.2 & 103.0 & 2.6 & 0.49 & 1.075 \\
\hline \hline
\end{tabular}

Table 3 presents the long-run findings of these four reforms in our pure life cycle model. The second row reports the long-run aggregate effects of eliminating the capital income tax by increasing the tax on labor income. In the long-run the labor income tax increases to $26.7 \%$. The increase in the labor supply distortion (from $31.2 \%$ to $39.6 \%$ ) and the decrease in the after-tax wage translate in a decrease in aggregate hours of about $3 \%$. On the other hand, the capital stock increases about $11 \%{ }^{20}$ Note that steady-state welfare declines with

\footnotetext{
${ }^{19}$ In the standard infinitely lived representative agent framework, the steady state interest rate is pinneddown by the subjective discount rate and this condition determines the steady state capital stock if labor supply is inelastic. Thus, whether the elimination of capital income tax is financed with labor income taxation or consumption taxation is irrelevant. Our model builds on this standard framework by adding, among other features, a life-cycle savings motive which turns out to be important for the effects of tax reforms on capital accumulation.

${ }^{20}$ In a similar framework but where labor supply is inelastic, İmrohoroğlu (1998) finds that capital stock increases by $21 \%$ due to the elimination of the capital income tax financed with labor income taxation. Auerbach and Kotlikoff (1987) find an increase of $11 \%$ in a model with elastic labor supply.
} 
this tax reform, a finding in line with previous results in Auerbach, Kotlikoff, and Skinner (1983) and İmrohoroğlu (1998). ${ }^{21}$

The third row presents the long-run effects of eliminating the capital income tax by increasing the tax on consumption. In the long-run the consumption tax rate increases to $15 \%$. Relative to the benchmark steady-state, labor supply decreases by about $2 \%$ which is consistent with the decrease of the after-tax wage as the effective marginal tax on labor income increases. The elimination of capital income taxation induces an increase in private saving and thus, in the long-run, the capital stock increases by $23 \%$. Notice that while both reforms induce similar effects on aggregate labor supply, using a consumption tax instead of a labor income tax to finance the elimination of the capital income taxation induces a larger increase aggregate saving.

As we previously discussed, by switching the tax burden towards the later periods in the life cycle, a consumption tax induces individuals to save more. As a result, the capital stock is $11 \%$ higher when the reform is financed with an increase in the consumption tax relative to an increase in the labor income tax. The fourth row of Table 3 reports the long-run aggregate effects of introducing a pure consumption tax (elimination of income taxation) In this case, the capital stock is $33 \%$ higher relative to the case where the labor income tax is increased. The differential impact of consumption and labor taxation on capital accumulation is quantitatively less important in a dynastic framework than in a pure life cycle model. Because in the dynastic framework individuals use intervivos transfers and bequests to smooth consumption in the dynasty, changes in the intertemporal allocation of the tax burden have smaller consequences for aggregate savings. Indeed, capital accumulation is only $6 \%$ higher when the labor income tax is set to zero relative to the case when the labor income tax is increased in the dynastic model.

The last row reports the effects of eliminating both the capital income tax and the social security system by increasing the consumption tax rate. In this case, the increase in the capital stock is $84 \%$ which is very large compared to $23 \%$ if social security were kept in place (see the third row of Table 3). The elimination of the social security system induces individuals to work $3 \%$ more which has a positive effect on savings. Moreover, since social security is a pay-as-you-go system its elimination increases the aggregate savings rate in the economy (by increasing the income of the young who have higher marginal propensity to save than the old).

We find that the effect of replacing all income taxation with a higher consumption tax increases the capital stock by $41.5 \%$ in the dynastic model while the increase in the capital stock in the life-cycle model is $47.7 \%$. Although the change in capital accumulation is quantitatively similar, the forces that raise the capital stock differ across the two frameworks. While in the dynastic framework the increase in the capital stock is driven by the fact that savings are quite interest elastic, in the pure life cycle model savings are not so interest elastic but the intertemporal reallocation of the tax burden stimulates savings.

\footnotetext{
${ }^{21}$ Erosa and Gervais (2002) show that Ramsey taxation in the economy of Auerbach, Kotlikoff, and Skinner (1983) features signifficant taxes on capital income. They show that an optimizing government taxes consumption and earnings at different rates along the life-cycle because the individuals' consumptionwork plan is not constant. If taxes cannot be conditioned on individuals' age, a non-zero capital income tax is optimal.
} 


\subsection{Transitions and Welfare Effects}

In this section, we compute the equilibrium transition paths from the same benchmark equilibrium to one of the three steady-states with a reformed tax structure to analyze their welfare effects. ${ }^{22}$ As previous research has shown, we anticipate that the incidence of the transitional costs will differ both across the affected cohorts and due to the nature of the tax reform. Relying on a higher consumption tax to balance the government's budget will primarily hurt the retirees and older cohorts, whereas using a higher wage tax will hurt the younger and poorer individuals more than other individuals.

Table 4 presents the fractions of individuals that are in favor of going along the transitional path to a reformed tax structure in the two calibrated models.

\begin{tabular}{lcrr}
\hline \multicolumn{2}{c}{ Table 4. Fraction of Individuals in Favor of Tax Reform } \\
\hline \hline & & Altruistic Model & Life Cycle Model \\
\cline { 3 - 4 }$\tau_{k}=0$, & $\tau_{n} \uparrow$ & 38.4 & 63.5 \\
$\tau_{k}=0$, & $\tau_{c} \uparrow$ & 45.7 & 37.3 \\
$\tau_{k}=\tau_{n}=0$, & $\tau_{c} \uparrow$ & 75.4 & 9.1 \\
\hline \hline
\end{tabular}

In the altruistic model, the reform with the widest support is the income tax elimination, which is also the one with the largest long-run gains. The reason for this result is the ability of dynasties to redistribute future welfare gains that will accrue to their descendants toward the current members of the dynasty by lowering bequests and changing the direction of inter vivos transfers. Life cycle individuals do not have access to this 'family' redistribution technology. The future generations who will be born into a steady-state with a much higher capital stock and wage will be better off relative to those born into the benchmark economy. However, the change in the tax structure alters the incentives to the current generations which respond by consuming less and working more and as a result they are much worse of relative to the benchmark fiscal policy. Due to the absence of links across cohorts in the life cycle model, a large fraction of the current cohorts will be worse off along this transitions.

A switch from the benchmark policy to a higher wage tax, on the other hand, gets more support in the life cycle model, (63.5\%), than the altruistic model (38.4\%). The elimination of the capital income tax financed with a higher labor income tax benefits individuals with high capital income relative to their earnings. These are middle age and older individuals in the pure life-cycle model who constitute more than $50 \%$ of the population. They benefit from the reform even though future generations are worse off because they do not care about their descendents. In contrast, in the dynastic model generations are linked through altruistic transfers and therefore the identity of the winners of such reform does not depend so much on their age. Instead, the winners are characterized by the current realization of the ability

\footnotetext{
${ }^{22}$ In all three tax reforms, we maintain the benchmark unfunded social security system. This allows us to focus entirely on tax reform. For the transitional effects of social security reform in the altruistic model, please see Fuster, İmrohoroğlu, İmrohoroğlu (2007). Auerbach and Kotlikoff (1987), Huang, İmrohoroğlu, and Sargent (1997), De Nardi, İmrohoroğlu, and Sargent (1999), and Conesa and Krueger (1999) study the transition to a privatized social security in a life-cycle model.
} 
shock which is correlated with their wealth holdings. High ability individuals are likely to have high capital income relative to earnings so they are the ones who benefit from the elimination of the capital income tax financed with a wage tax. Those individuals amount to less than $40 \%$ of the population in the dynastic model.

Given this sharp difference between the policy recommendations for tax reform across the two constructs, the policy maker needs to have a strong prior on the model that most closely approximates the actual U.S. economy.

\subsubsection{Switch to Higher Wage Taxation.}

Transitional Paths. In this experiment the government sets the capital income tax rate to zero at period 1 and increases the labor income tax rate in order to finance its (fixed) purchases of goods and services. In both models, at period 1 of the reform the labor income tax increases from $17.3 \%$ to $28 \%$. It starts decreasing towards its long-run value of $25 \%$ in the altruistic model and $26.7 \%$ in the pure life-cycle model. ${ }^{23}$

We find that the transitional paths for the after-tax factor prices are very similar across the two models. Thus, in Figures 4.1 to 4.2, we present transitional paths for the altruistic model only. Figure 4.3 shows that the after-tax wage decreases at the first period of the transition and then increases towards the same value as the capital-labor ratio increases. The after tax interest rate changes in opposite direction relative to the after tax wage and converges to a higher long-run value.

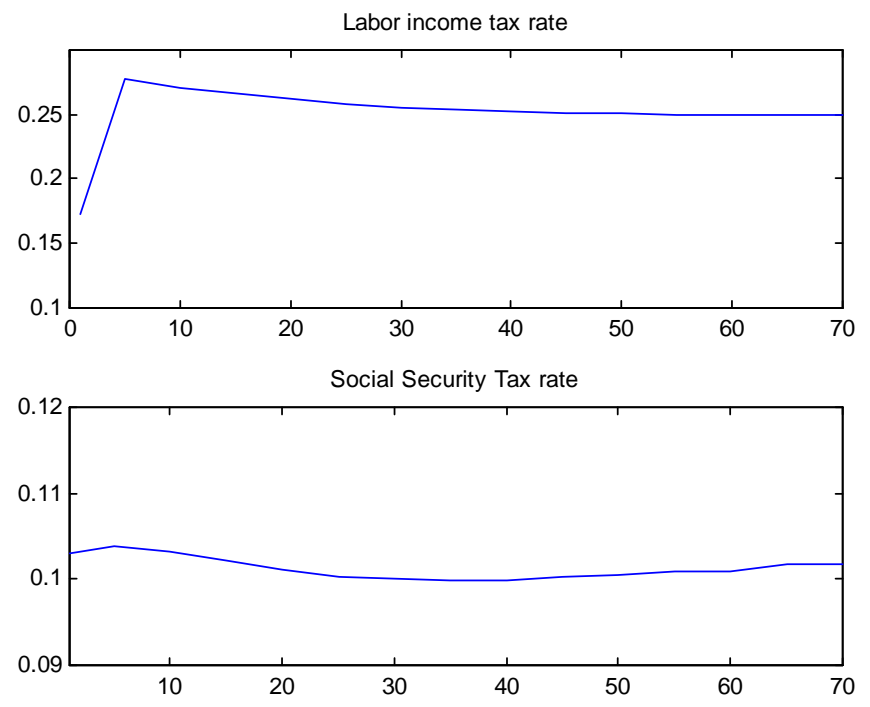

Figure 4.1: Taxes Under Switch to Higher Wage Tax

\footnotetext{
${ }^{23}$ In the first period of the transition the social security tax rate increases and then it decreases towards a slightly lower steady state value.
} 
The elimination of the capital income tax induces higher savings resulting in an increasing capital stock over time. Labor supply decreases in period 1 of the transition due to the higher tax burden on labor income. The effective labor supply and the fraction of time working converge towards lower steady state levels (see Figure 4.2).

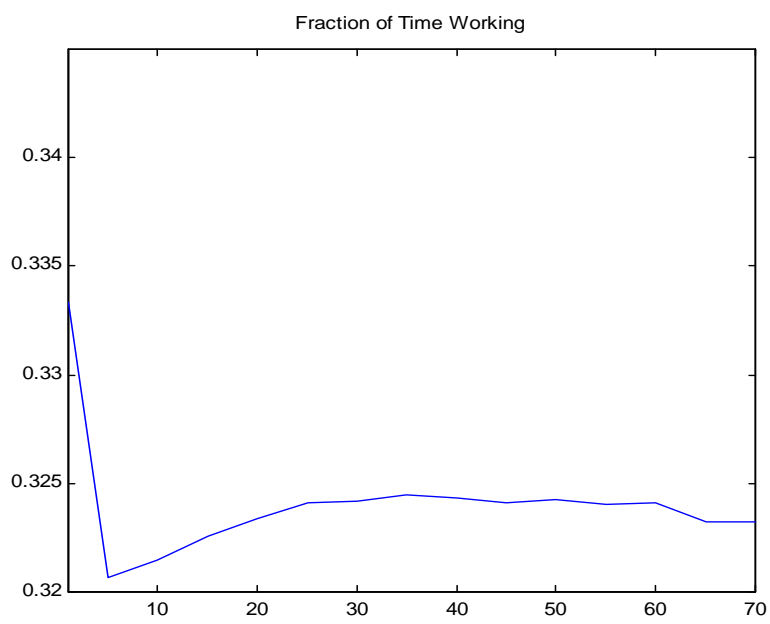

Figure 4.2: Fraction of Time Worked Under Switch to Higher Wage Tax

The transitional paths of capital and labor imply that the capital-labor ratio increases along the transition. The increase in the capital-labor ratio raises the after-tax wage in the long-run. The long-run increase in the after-tax interest rate is explained by the elimination of the capital income tax (see Figure 4.3). Notice that in the long-run, the after-tax wage does not change. This indicates that the decrease of labor supply in the long-run is due to the fact that individuals are richer (increase in capital income), an income effect induce them to work less.

\section{Welfare Effects}

Altruistic Model In Figures 4.4 and 4.5 we report the welfare effects of the tax reform on the different households alive at the time of the tax change (period 1 of transition) for the altruistic model. We compute the consumption compensation (constant in time and across states of nature) necessary to make the household indifferent between living at the initial steady state and at the economy under reform. We report the consumption compensations for different types of households regarding their demographic composition (types 1 (no parents alive) and 3 (parents and children alive)), age, and education (for instance, $H L$ means that parents are college type and children are non-college type). ${ }^{24}$ For each of these types we

\footnotetext{
${ }^{24}$ We do not report the welfare effects for households of type 2 (no children alive) because they are a small fraction of the population. Our calibration of the demographic parameters implies that $79.2 \%$ of individuals
} 

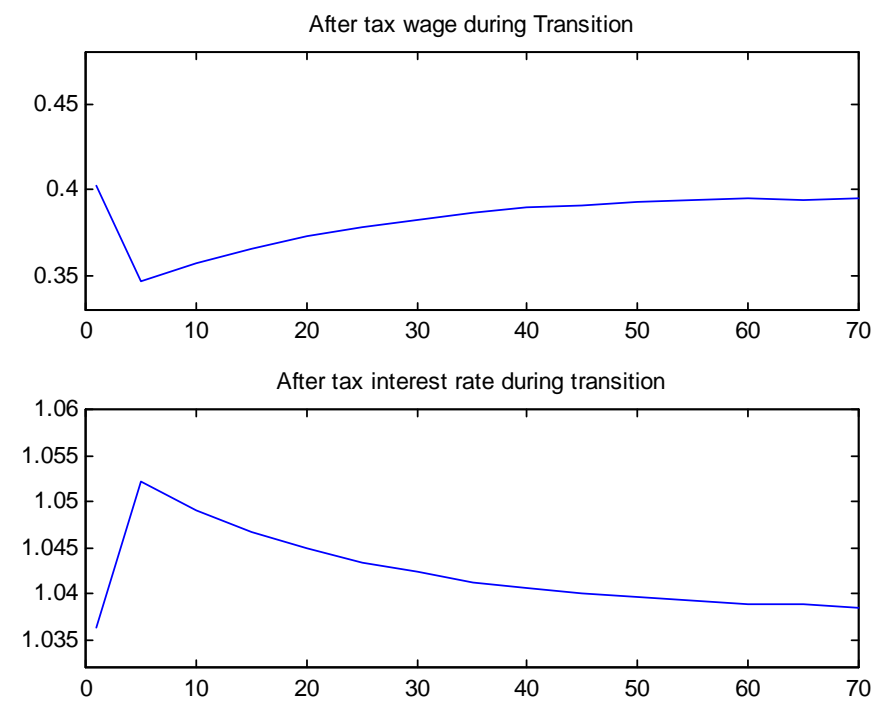

Figure 4.3: Prices Under Switch to Higher Wage Tax

aggregate the consumption compensations across assets levels and realizations of the labor productivity shocks using their distributions at the initial steady state equilibrium.

For households of Type 1 (those without parents) we find that they benefit more with the reform the older they are (see Figure 4.4). Younger households are more likely to be borrowing constrained and suffer more from the increase in the labor income tax. Households where the parents have low ability $(L H$ and $L L)$ are also relatively poorer which explains why they do not benefit from the reform as much as the $H H$ and $H L$ types. ${ }^{25}$ Poorer households lose with this reform because their capital income to earnings ratio is low and, thus, the reform increases their tax payments. Notice also that given an ability of the parent, the consumption compensation increases with the ability of the children. Because the dynasty self-insures against the ability shock by saving in good times (when children are ability $\mathrm{H}$ ) and dissaving in bad times, the increase in the interest rate is more beneficial if the children are high ability than otherwise (for instance, compare $H H$ with $H L$ ).

Figure 4.5 shows that in households of Type 3 the consumption compensations are relatively flat (in these households parents are of age 55 to 85). In these households the parents are alive and transfer resources to the young members of the household. Intervivos transfers ease the borrowing constraints for young individuals so the welfare benefits of the reform are not necessarily increasing with age. The key factor that determines whether a household wins or loses with the reform is the ability of the parent. The higher is the ability of the

belong to a household of type $3,20 \%$ belong to a household of type 1 , and only $0.8 \%$ belong to a household of type 2 .

${ }^{25}$ Although the parent is not alive, his ability is a relevant variable because it is correlated with the wealth of the household. For a given age and ability of the children, the household is richer the larger the ability of the parent was. 


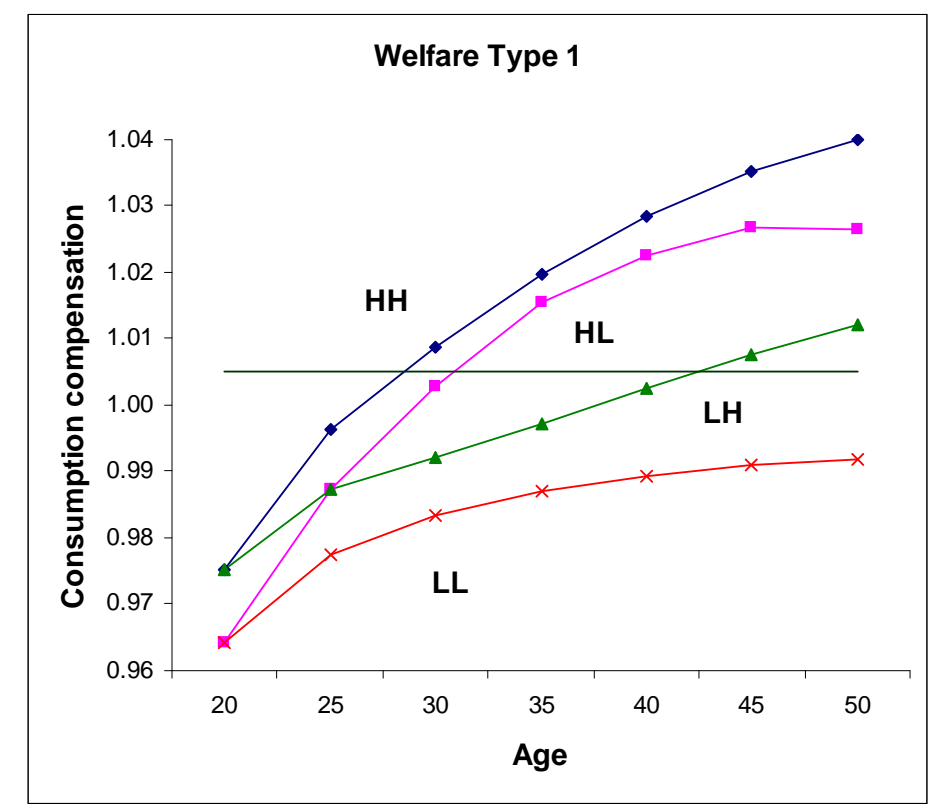

Figure 4.4: Welfare under Switch to Higher Wage Tax

parent, the larger is the capital income to earnings ratio and the lower is the tax burden under this reform. We find that Type 3 households of abilities $H H$ and $H L$ benefit from the reform regardless of their age. Their welfare gains are between $2 \%$ and $4 \%$ of consumption at the initial steady state.

In the altruistic model $38.4 \%$ of the households support the transition to a higher wage tax rate.

Pure Life-Cycle Model In the pure life cycle model, on the other hand, $63.5 \%$ of the individuals alive at the time of the reform support this reform. As can be seen in Figure 4.6 only individuals of ages 20 to 30 are hurt by this reform which shifts the tax burden from capital income to labor income. Since young individuals are more likely to be borrowing constrained, they are hurt by the increase in the wage tax. Notice that the decrease in welfare is larger for young individuals of high ability who face a steeper labor productivity profile and, thus, are more likely to be borrowing constrained. Middle aged and old individuals have a higher capital income to earnings ratio and, thus, this tax reform decreases their tax payments. As high ability individuals are richer their welfare gains are larger than those of individuals of low ability for ages 35-85.

\subsubsection{Switch to Higher Consumption Taxation}

Transitional Paths. In this experiment the government sets the capital income tax rate to zero at period 1 and increases the consumption tax rate in order to finance its (fixed) expenditures while the labor income tax remains constant (17.3\%). 


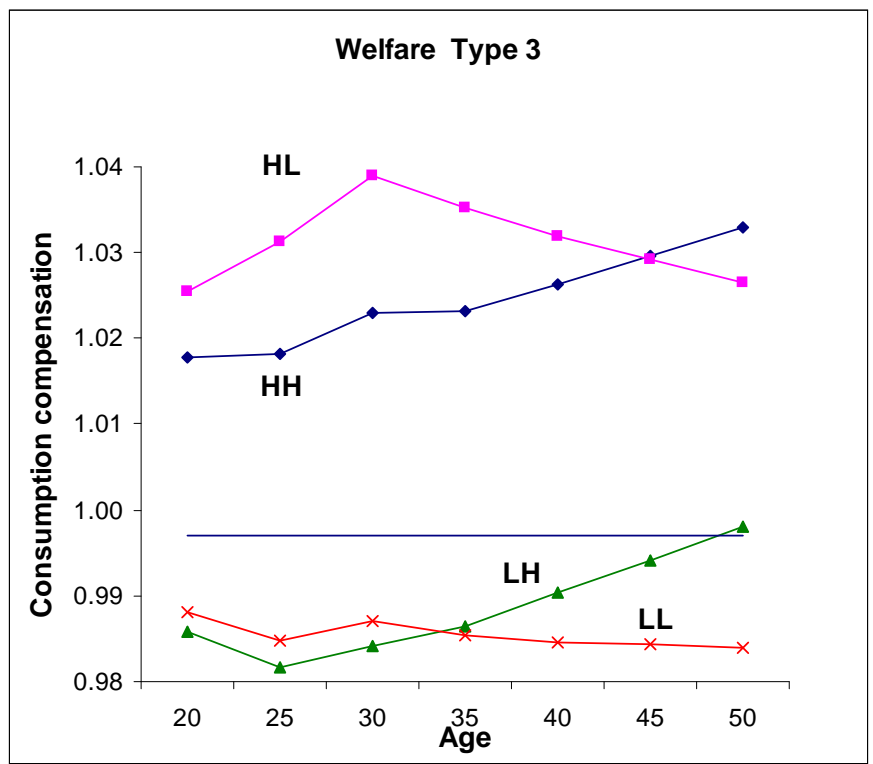

Figure 4.5: Welfare of Type 3 under Switch to Higher Wage Tax

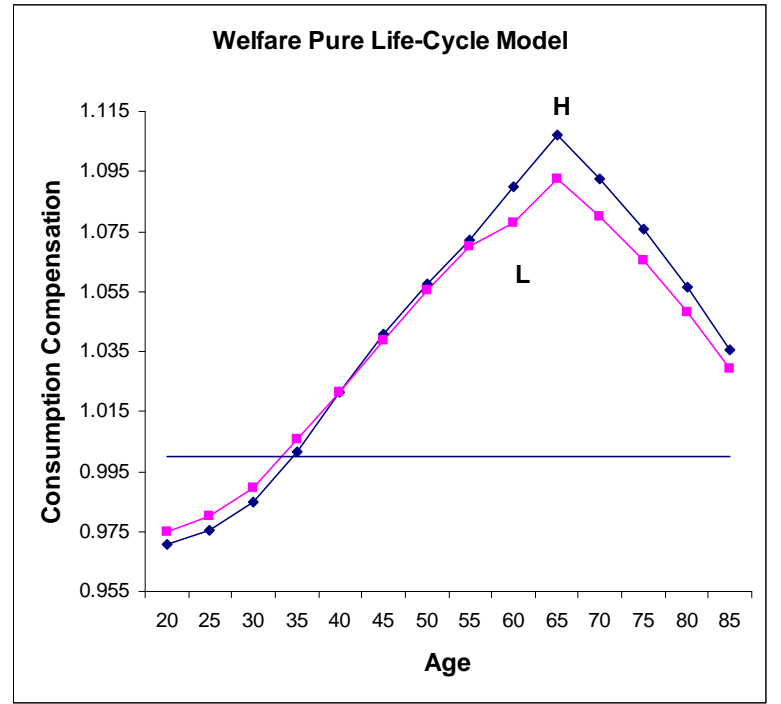

Figure 4.6: Welfare Pure Life-Cycle under Switch to Higher Wage Tax 
In the altruistic model, in the first period of the reform the consumption tax rate increases from $5.5 \%$ to $19 \%$ and then it starts decreasing towards the long-run value of $14.5 \%$. We find that $45.7 \%$ of individuals benefit from this tax reform. In the pure life-cycle model the consumption tax rate increases to $18 \%$ and then it starts decreasing towards the long-run level of $15 \%$. In this framework $37.3 \%$ of individuals alive when the tax reform takes place benefit from it.

In both models, at period 1 of the transition, the labor supply decreases. At this period, the consumption tax rate and the labor tax rate imply an effective marginal tax on wages of $30.5 \%$ which is higher than the initial value of $21.6 \%$. The after-tax wage increases during the transition towards a higher long-run level. This is because the capital labor ratio increases along the transition while the tax rate on labor income is constant. In addition. the effective labor supply decreases as individuals decide to work less. The fraction of time worked decreases in period 1 of the transition and converges to a lower long-run level. After period 1 of the reform, consumption tax decreases while the payroll tax rate of social security changes non-monotonically. In particular, from year 40 on the social security tax increases which can explain the decrease in the fraction of time that individuals work.

\section{Welfare Effects}

Altruistic Model Younger and poorer households of type 1 are worse off in this tax reform. Since their capital income is low relative to their consumption, this tax reform induces an increase in their tax base Notice that the welfare losses for these individuals are lower under this reform than under experiment 1 (increase in labor income tax). For instance, the compensating variation in consumption is $-2 \%$ in this experiment while it is $-4 \%$ in experiment 1 for age-20 individuals with low ability. Since a consumption tax implicitly taxes the initial asset holdings, borrowing constrained individuals prefer such a reform rather than an increase in the labor income tax. On the contrary, the richer and older individuals prefer an increase in the labor income tax since their initial assets holding are taxed by the consumption tax. Notice that the welfare gains are smaller compared to the ones implied by the change in the labor income tax (for age-50-individuals of ability $H H$ the gain is $3 \%$ of initial consumption while it is $3.5 \%$ in experiment 1 ).

As in experiment 1 , the consumption compensations are relatively flat for Type 3 households while they are increasing with age for Type 1 households (see Figure 4.8). Type 3 households have parents of ages 55-85 and their children of ages 20-50. The elimination of the capital income tax induces an increase of the income of older individuals (parents) relative to the income of younger individuals (children). Since individuals are altruistic, parents transfer to their children part of the increase in their income. In this way the household can smooth consumption across generations in the dynasty. As a result, the welfare gains are not as increasing with age as those for Type 1 households.

The welfare effects of this reform are smaller (in absolute value) relative to the ones implied by experiment 1 (change in the labor income tax). The increase in the consumption tax implies a tax on initial assets which hurts richer households relative to poorer households. As a result, for $H H$ and $H L$ households the welfare gains are smaller while for $L H$ and 


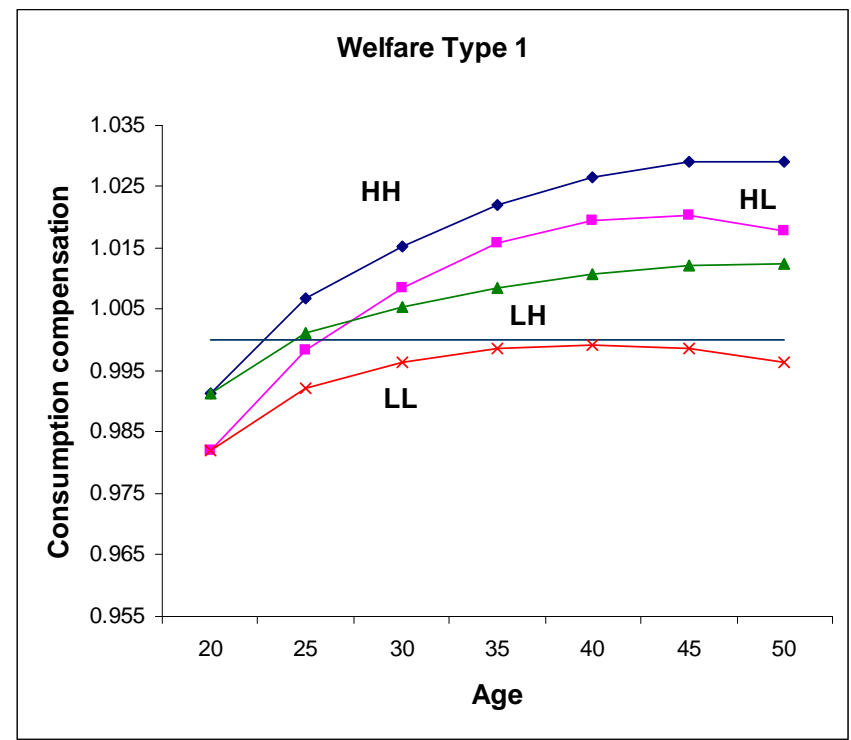

Figure 4.7: Welfare of Type 1 under Switch to Higher Consumption Tax

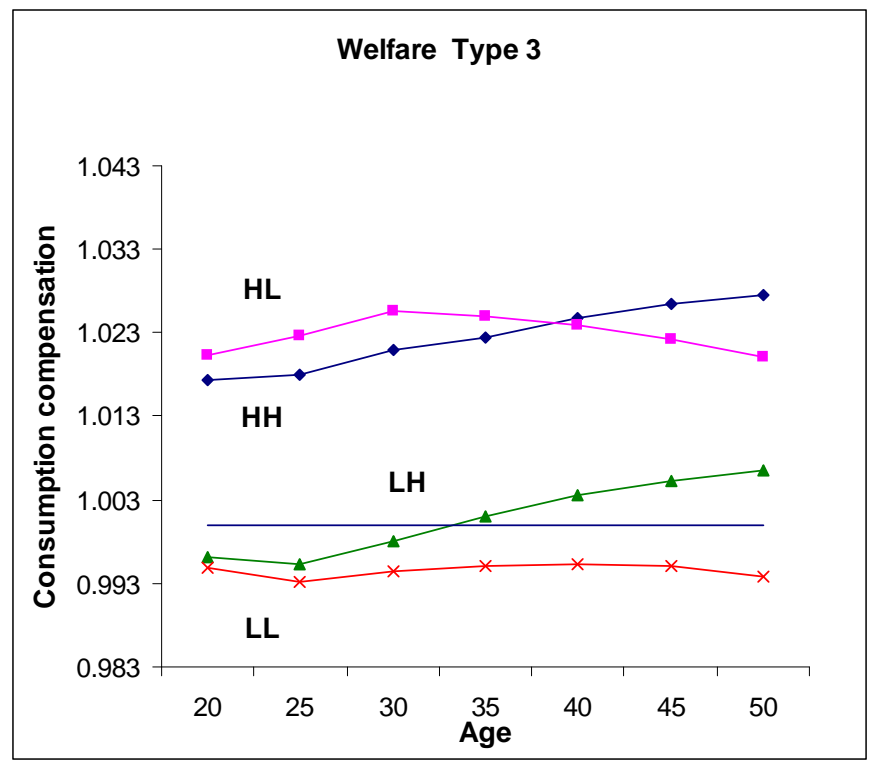

Figure 4.8: Welfare of Type 3 under Switch to Higher Consumption Tax 


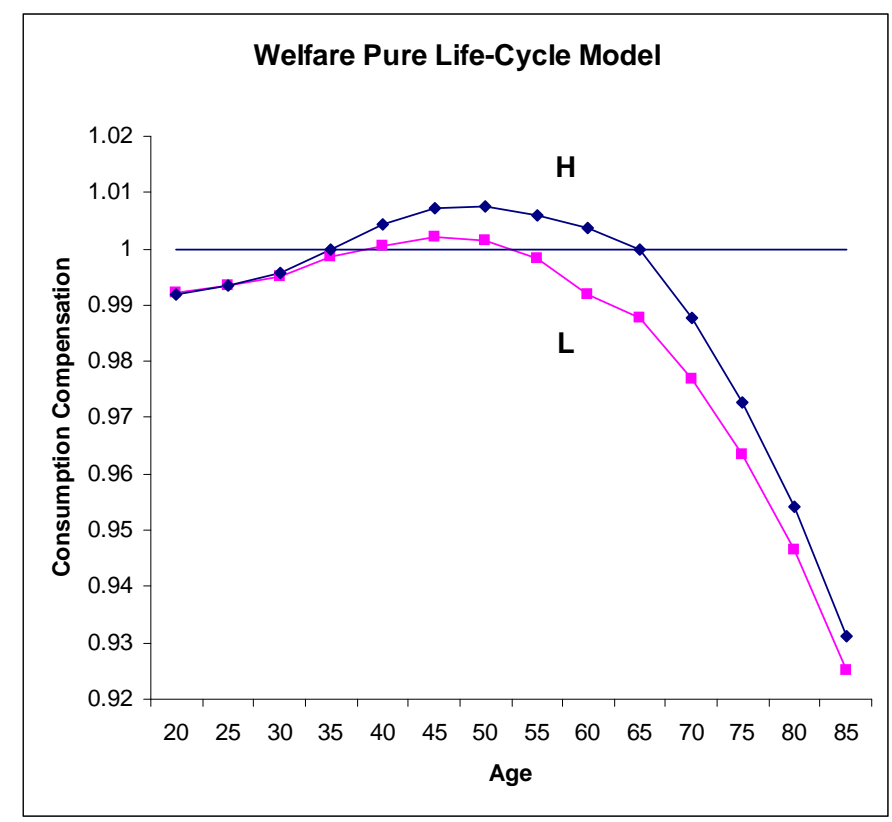

Figure 4.9: Welfare of Pure Life-Cycle Households under Switch to Higher Consumption Tax

$L L$ households the welfare loses are smaller than the ones implied by experiment 1 . By financing the reform with a consumption tax, the household $L H$ of ages 40-50 gains from the elimination of the capital income tax. While both $L L$ and $L H$ households are relatively poor (the father has low ability and thus accumulated low wealth), only household where the children have low ability $(L L)$ loses from the elimination of the capital income tax. This is because the household $L L$ is dissaving while the household $L H$ is saving. In this economy, households self-insure against the ability shock by saving when they receive a positive shock and dissaving when they receive a negative shock and, in this way, they smooth consumption across generations in the dynasty.

Pure Life-Cycle Model The welfare effects of this reform, that are displayed in 4.9, are non-monotone with respect to individuals' age in the pure life-cycle model. The switch towards taxing consumption hurts the poor and borrowing constrained young individuals of ages 20-30 as in the first experiment. The tax reform is more attractive for middle age individuals because their consumption to capital income ratio is smaller than that of younger individuals (ages 20-30). The tax reform also hurts the retired individuals who have a high consumption to capital income ratio because they are dissaving. Notice also that this reform hurts low ability individuals (poorer) more than the high ability individuals (richer) for any age group. 


\subsubsection{Elimination of Income Taxation and Switching to a Pure Consumption Tax}

In this experiment, we explore the welfare effects of eliminating both the capital and the labor income taxes substituted by a consumption tax. In this reform the government sets both the labor income tax and capital income tax rates to zero immediately.

In the altruistic model, at period 1 of the reform the consumption tax rate increases from $5.5 \%$ to $41 \%$ to finance the fixed government purchases. Then, the consumption tax rate decreases towards the long-run level of $35 \%$. We find that the majority of individuals, $75.4 \%$, alive at the time of the tax reform benefit from it.

In the pure life-cycle model, at the first period of the transition, the consumption tax rate increases to 0.44 and then decreases towards the long-run value of 0.37 . We find that only $9.1 \%$ of individuals benefit from the substitution of income taxation by consumption taxation.

Transitional Paths. In the first period of the transition the after-tax wage and interest rates increase because the income tax is set to zero. From period 2 on, the interest rate decreases while the wage increases because the capital-labor ratio increases along the transition. ${ }^{26}$
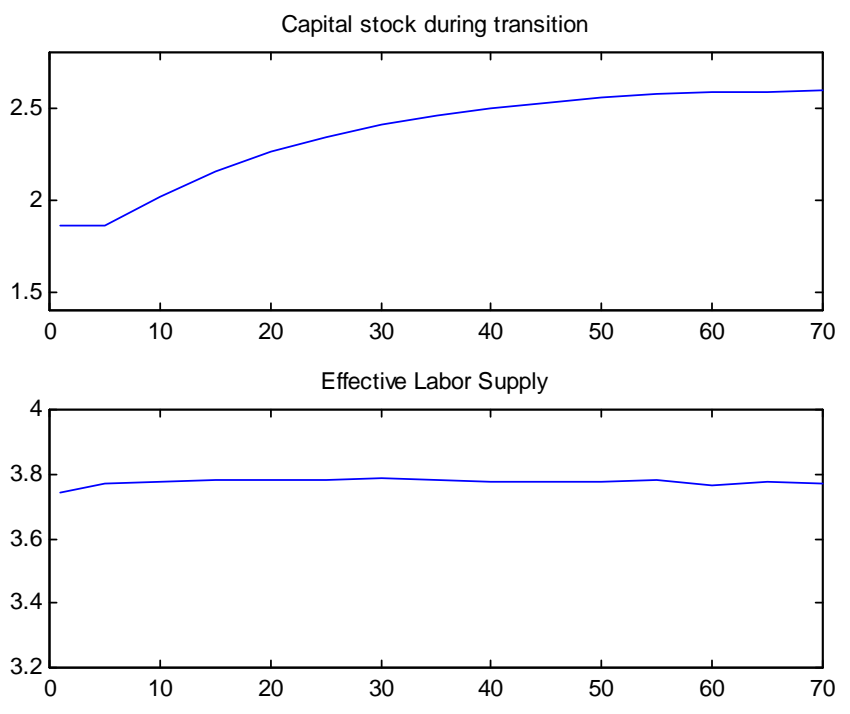

Figure 4.10: Elimination of Income Taxes

The shift to consumption taxation implies an effective tax on wages of $29 \%$ in the first period and $26 \%$ in the long-run which represents an increase relative to the initial tax (21.6\%). Even though the implicit taxation of wages is higher, individuals supply more labor (see Figure 4.10 ). Individuals work more because an income effect from the taxation

\footnotetext{
${ }^{26}$ The results for the pure life cycle model are very similar, and therefore omitted.
} 
of initial assets by the higher consumption tax. The increase in the after-tax interest rate also induces individuals to increase their labor supply (see Fig 4.11).

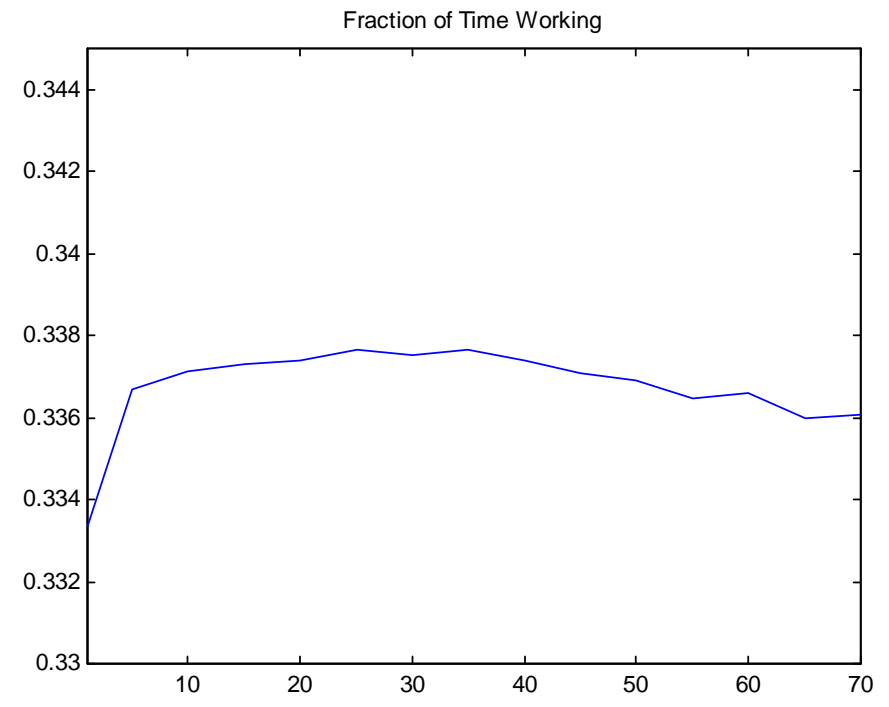

Figure 4.11: Elimination of Income Taxes

\section{Welfare Effects}

Altruistic Model In principle we expect households to benefit from this reform if their tax base is reduced. That is, households whose consumption is lower than income are likely to prefer a consumption tax to an income tax. We find that all households of Type 1 (no parents alive) benefit from this tax reform. Notice that, the consumption compensation exhibits a non-monotonic relation with the age of the household (see Figure 4.12). Older households are likely to be richer and benefit from the elimination of the capital income tax. However, they suffer an implicit taxation of their initial assets due to the higher consumption tax. Because of these opposite effects, the consumption compensation does not differ much across households with different asset levels. Indeed, for a given age and labor ability of the children, the consumption compensations are similar (for instance the ones for $H H$ and $L H$ ) across households with different parent's ability (wealth level).

For households of Type 3 (parents and children are alive), we find that all ability types benefit from the reform except the younger household of abilities $L L$ (see Figure 4.13). This household prefers the taxation of income because it has a high marginal propensity to consume. The switch to consumption taxation implies an increase in their tax burden for the $L L$ type because their tax base is higher with consumption taxation than with income taxation. For these households consumption exceeds income because consumption is financed by depleting accumulated assets. 


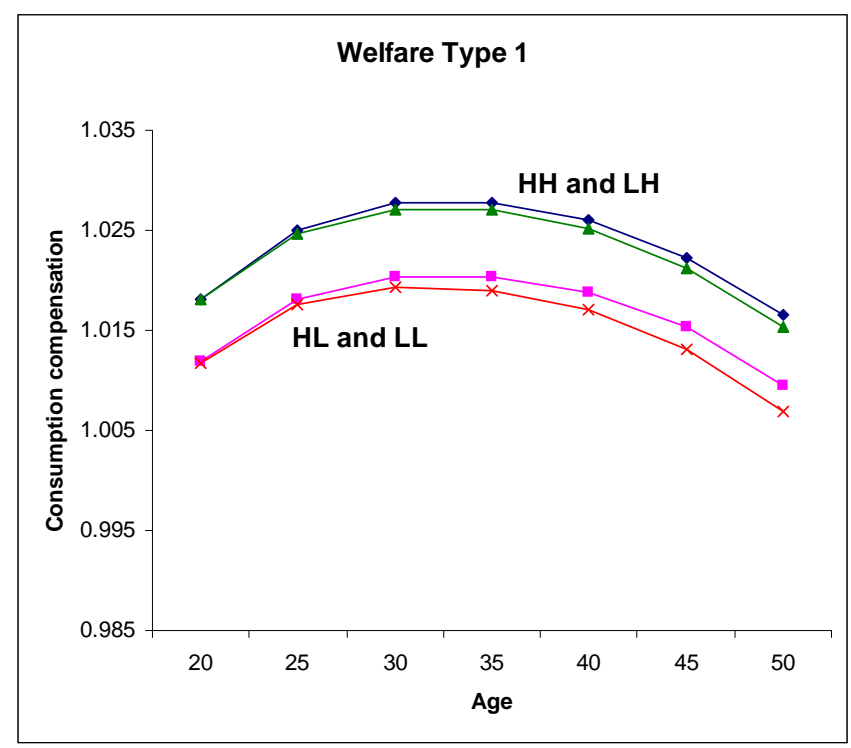

Figure 4.12: Welfare of Type 1 under Elimination of Income Taxes

In this economy where households self-insure by accumulating capital in good times and consuming the capital in bad times, it seems that a progressive consumption tax could be beneficial. A progressive consumption tax would provide some insurance against the labor market risk.

Pure Life-Cycle Model The results for this reform are very different in the pure life-cycle model. Only $9.1 \%$ of the individuals support this reform. As can be seen in Figure 4.14 almost all age groups except for the very young experience a welfare loss during the transition. Older individual suffer the most since their consumption is higher relative to their income. The tax base increases more for the older households relative to younger households.

It is important to point out that even though this reform is welfare improving in the long run (according to the steady state results) it does not generate much support once the transitional dynamics are taken into account. The next figure plots the consumption compensation for different generations alive at some moment of the transition (see Figure 4.15).

Figure 4.15 shows that this tax reform has very large welfare gains for the future generations which amount up to $5.4 \%$ of lifetime consumption. For generations alive at the moment of the reform, the shift towards consumption taxation generates an important redistribution of the tax burden away from working and younger individuals and towards wealthier and older individuals. At the initial period of the transition, 20-years-old individuals are indifferent between the reform or the initial steady state. However, at later periods in the transition, 20-years-old individuals prefer the consumption tax to an income tax. These future generations benefit from a larger capital stock, after-tax wage, and interest rates.

We conclude from these three tax reforms that, in the pure life-cycle model, the larger 


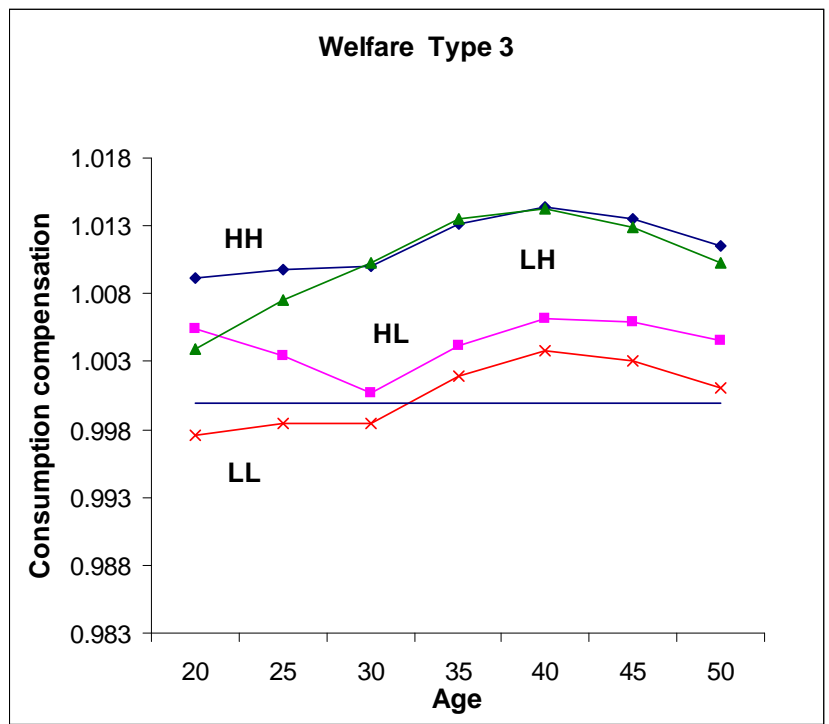

Figure 4.13: Welfare of Type 3 under Elimination of Income Taxes

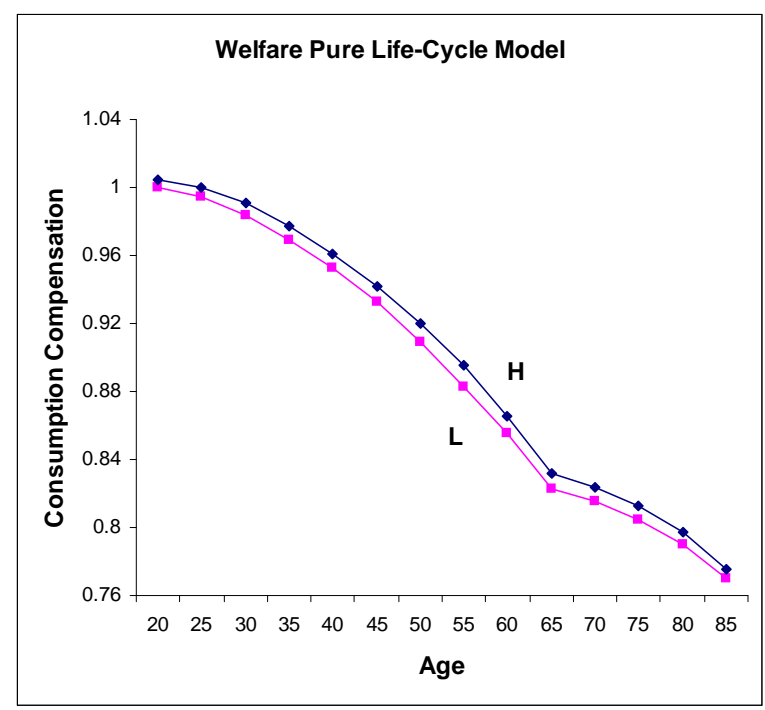

Figure 4.14: Elimination of Income Taxes 


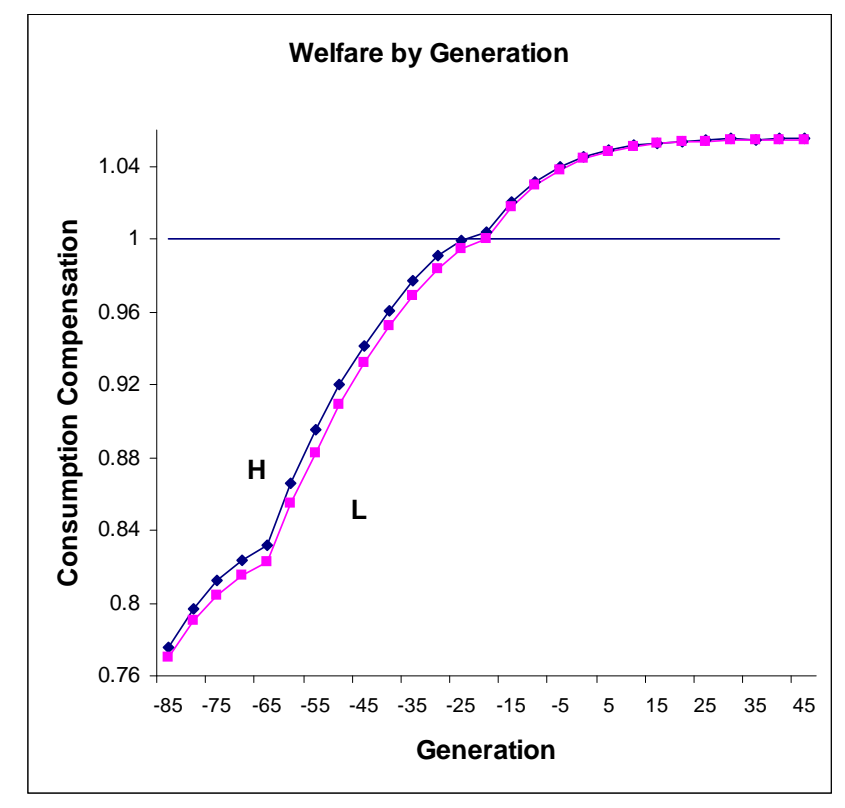

Figure 4.15: Welfare by Generation under Elimination Income Taxes

are the long-run welfare gains the lower is the support for the reform by the generations alive at the moment of the reform and the other way around. The elimination of income taxation is the reform with lowest support (only $9 \%$ of population) and the one with largest future welfare gains. In the dynastic framework, on the other hand, the reform with most support is the elimination of income taxation, which is also the reform with largest long-run welfare gains. Dynasties are able to redistribute the future welfare gains towards the present by lowering the bequests and by changing their intervivos transfers.

\section{Sensitivity Analysis}

In the pure life cycle model, a relatively high value of $\beta=1.038$ was needed to hit our calibration target of $K / Y=3$. This value for the subjective discount factor might overemphasize consumption gains that accrue later in the life cycle when the tax structure is altered. In order to evaluate the sensitivity of our results to this parameter, we recalibrate $\sigma=2$ and choose the value for $\beta$ to match a capital to output ratio of 3 . In the life-cycle model, we find that such value is $\beta=1.011$. This calibration implies a coefficient of relative risk aversion of $1.31(1-\nu(1-\sigma))$ while this coefficient is 1.93 in the original calibration. This alternative calibration implies that on average individuals work a fraction 0.33 of their discretionary time. 


\begin{tabular}{rrrrrrr}
\hline \multicolumn{6}{c}{ Table 5: Tax Reform in the Life-Cycle Model } \\
\hline \hline \multicolumn{1}{r}{$\tau_{k}$} & $\tau_{n}$ & $\tau_{c}$ & \multicolumn{1}{c}{$\tau_{s s}$} & \multicolumn{1}{c}{$K$} & \multicolumn{1}{c}{$N$} & $C V$ in $C$ \\
\hline & & & & & & \\
35 & 17.4 & 5.5 & 9.8 & 100.0 & 100.0 & 1.000 \\
0 & 25.4 & 5.5 & 9.6 & 118.8 & 98.1 & 1.003 \\
0 & 17.4 & 14.5 & 9.6 & 127.5 & 99.0 & 1.008 \\
0 & 0 & 35.1 & 9.7 & 145.4 & 100.5 & 1.016 \\
\hline \hline
\end{tabular}

Table 5 shows the long run effects of tax reform in the life-cycle model under this alternative calibration. The quantitative findings are very similar to those in the benchmark calibration which are presented in Table 3. Eliminating capital income taxation raises the stock of capital and the largest gains come from the elimination of income taxation. Table 6 below shows the fraction of individuals in favor of tax reform after taking into account the transitional path. Similar to our earlier finding in Table 4, the tax reform with the largest steady-state gain gets the least popular support.

\begin{tabular}{|c|c|c|c|c|}
\hline & \multicolumn{2}{|c|}{ Altruistic Model } & \multicolumn{2}{|c|}{ Life-Cycle Model } \\
\hline & $\beta=0.99$ & $\beta=0.98$ & $\beta=1.038$ & $\beta=1.011$ \\
\hline & $\sigma=4$ & $\sigma=2$ & $\sigma=4$ & $\sigma=2$ \\
\hline$\tau_{k}=0, \Delta \tau_{l}$ & 38.4 & 49.3 & 63.5 & 63.1 \\
\hline$\tau_{k}=0, \Delta \tau_{c}$ & 45.7 & 71.5 & 37.3 & 46.2 \\
\hline$\tau_{l}=\tau_{k}=0$ & 75.4 & 96.1 & 9.1 & 14.9 \\
\hline
\end{tabular}

In Table 7 , we present the long run effects of tax reform in the altruistic model under the alternative calibration with $\sigma=2$ and $\beta=0.9824$ which implies $K / Y=3$.

\begin{tabular}{rrrrrrr}
\hline \multicolumn{6}{c}{ Table 7: Tax Reform in the Altruistic Model } \\
\hline \hline \multicolumn{1}{c}{$\tau_{k}$} & \multicolumn{1}{c}{$\tau_{n}$} & \multicolumn{1}{c}{$\tau_{c}$} & \multicolumn{1}{c}{$\tau_{s}$} & \multicolumn{1}{c}{$K$} & \multicolumn{1}{c}{$N$} & $C V$ in $C$ \\
\hline $35 \%$ & $16.6 \%$ & $5.5 \%$ & $10.4 \%$ & 100.0 & 100.0 & 1.000 \\
0 & $23.9 \%$ & $5.5 \%$ & $10.4 \%$ & 134.5 & 97.4 & 1.012 \\
0 & $16.6 \%$ & $14.3 \%$ & $10.2 \%$ & 136.9 & 98.7 & 1.014 \\
0 & 0 & $34.4 \%$ & $10.4 \%$ & 141.5 & 100.9 & 1.016 \\
\hline \hline
\end{tabular}

The results in Table 7 are quantitatively very close to those in Table 2, with one exception. The welfare gains from tax reform with this alternative calibration are smaller. 


\section{Conclusions}

We use two calibrated general equilibrium models with heterogenous agents facing incomplete markets to evaluate various tax reforms. First, we specify an altruistic model with perfect family insurance. Individuals face both permanent lifetime ability shocks and uninsurable idiosyncratic income shocks over their life cycle. The family is an informal mechanism to provide insurance against these risks as well as the longevity risk. Bequests and inter vivos transfers are used to serve these insurance demands. A significant change in fiscal policy such as the elimination of capital income taxation, significantly alters the after-tax factor prices and provides huge incentives to change optimal decisions of the households. Second, a pure life cycle model provides a very different environment as the individuals can only self-insure against these same ability, income and mortality risks. In addition, they also have a significant desire to save for retirement. These differing motives to save result in quantitatively different responses to tax reform in the two economies.

Computation of the transitional paths help us produce detailed welfare effects on all generations following a reform. In both cases, eliminating the capital income tax by raising the labor income tax hurts the younger generations who may also be facing borrowing constraints. On the other hand, when a higher consumption tax is used to eliminate all of income taxation, long run gains are highest in both models. However, in both cases, the increased consumption tax hurts the retirees the most. In the altruistic model, the family serves as a very effective insurance mechanism and we find that a majority of the individuals are better off transitioning from the benchmark fiscal policy toward the reformed steady-state where there is no income taxation. The dynastic links work as an informal redistribution mechanism to deliver some of the future gains to current generations. In the life cycle model, individuals do not have any generational links and this backward transfer is not possible. As

a result, life cycle individuals are worse off when income taxation is eliminated and replaced by a consumption tax. 


\section{References}

[1] Aiyagari, R. (1995). 'Optimal Capital Income Taxation with Incomplete Markets, Borrowing Constraints, and Constant Discounting', Journal of Political Economy, volume $103,1158-75$.

[2] Albanesi, S. and C. Sleet (2006). 'Dynamic Optimal Taxation with Private Information', Review of Economic Studies 73:1-30

[3] Altig, D., A. Auerbach, L. Kotlikoff, K. Smetters, and J. Walliser (2001). "Simulating Fundamental Tax Reform in the U.S.", American Economic Review, (June, 2001), 91, 3: 574-595.

[4] Auerbach, A. J. and Kotlikoff, L. J. (1987). Dynamic Fiscal Policy, Cambridge University Press, New York, N. Y.

[5] Auerbach, A., L. Kotlikoff, and J. Skinner (1983). 'The Efficiency Gains from Dynamic Tax Reform', International Economic Review 24 (2), 81-100.

[6] Bureau of the Census. (1991). Money Income of Households, Families, and Persons in the United States.

[7] Castañeda, A., Díaz-Giménez, J. and Ríos-Rull, V. (2003). 'Accounting for the U.S. Earnings and Wealth Inequality', Journal of Political Economy 111(4), 818-857.

[8] Chamley, C. (1986). 'Optimal Taxation of Capital Income in General Equilibrium with Infinite Lives", Econometrica 54(3), May, pp. 607-622.

[9] Conesa, Carlos, Sagiri Kitao, and Dirk Krueger (2006), 'Taxing Capital? Not a Bad Idea After All!', NBER Working Paper No. 12880.

[10] Conesa, J. C. and Krueger, D. (1999). 'Social Security Reform with Heterogeneous Agents', Review of Economic Dynamics 2 (4), 757-795.

[11] Conesa, J. C. and Krueger, D. (2006). 'On the Optimal Progressivity of the Income Tax,' Journal of Monetary Economics 53(7): 1661-1691.

[12] Coronado, J. L., Fullerton, D. and Glass, T. (2000). 'The Progressivity of Social Security', NBER Working Paper 7520.

[13] De Nardi, M. (2004). 'Wealth Inequality and Intergenerational Links', Review of Economic Studies 71, number 3, 743-768.

[14] De Nardi, M., İmrohoroğlu, S. and Sargent, T. J. (1999). 'Projected U.S. Demographics and Social Security', Review of Economic Dynamics 2, number 3, 638-665.

[15] Elo I. and Preston, S. (1996). 'Educational Differences in Mortality: United States, 1979-1985', Social Science and Medicine 42, 47-57. 
[16] Erosa, A. and Gervais, M. (2002). 'Optimal Taxation in Life-Cycle Economies', Journal of Economic Theory 105, 338-369.

[17] Erosa, A. and Koreshkova, T. (2006). 'Progressive Taxation in a Dynastic Model of Human Capital', Journal of Monetary Economics, forthcoming.

[18] Fuster, L. (1999). 'Is Altruism Important for Understanding the Long-Run Effects of Social Security?', Review of Economic Dynamics 2, number 3, 616-637.

[19] Fuster, L., İmrohoroğlu, A and İmrohoroğlu, S. (2003). 'A Welfare Analysis of Social Security in a Dynastic Framework', International Economic Review 44, number 4, 1247 1274.

[20] Fuster, L., İmrohoroğlu, A and İmrohoroğlu, S. (2007), 'Elimination of Social Security in a Dynastic Framework', Review of Economic Studies 74 (1), pp. 113-145.

[21] Gale, W. G. and Scholz, J. K. (1994). 'Intergenerational Transfers and The Accumulation of Wealth', Journal of Economic Perspectives 8, number 4, 145-61.

[22] Garriga, Carlos (2003), 'Optimal Fiscal Policy in Overlapping Generations Models,' manuscript, Florida State University.

[23] Golosov M., N. Kocherlakota, and A. Tsyvinski (2003). 'Optimal Indirect and Capital Taxation,' Review of Economic Studies 70 (3), July, pp. 569-587.

[24] Güvenen, F. (2005). 'An Empirical Investigation of Labor Income Processes', manuscript, University of Rochester.

[25] Huang, H., İmrohoroğlu, S. and Sargent, T. J. (1997). 'Two Computations to Fund Social Security', Macroeconomic Dynamics 1 (1), 7-44.

[26] İmrohoroğlu, S. (1998). 'A Quantitative Analysis of Capital Income Taxation', International Economic Review 39 (2): 307-328.

[27] İmrohoroğlu, A., İmrohoroğlu, S. and Joines, D. (1999). 'Social Security in an Overlapping Generations Economy with Land', Review of Economic Dynamics 2, number 3, 638-665.

[28] Judd, K. (1985). 'Redistributive Taxation in a Simple Perfect Foresight Model,' Journal of Public Economics 28(1), October, pp. 59-83.

[29] Kocherlakota N. (2005). 'Zero Expected Wealth Taxes: A Mirrlees Approach to Dynamic Optimal Taxation', Econometrica,73 (2005): 1587-1621

[30] Krusell, P. and Smith, A. A. (1998). 'Income and Wealth Heterogeneity in the Macroeconomy', Journal of Political Economy 106(5), 867-896.

[31] Laitner, J. (1992). 'Random Earnings Differences, Lifetime Liquidity Constraints, and Altruistic Intergenerational Transfers', Journal of Economic Theory 58,135-170. 
[32] Prescott, E. (2004). 'Why Do Americans Work So Much More Than Europeans?', Federal Reserve Bank of Minneapolis Quarterly Review Vol. 28, No. 1, July 2004, pp. 2-13.

[33] Solon, G. (1992). 'Intergenerational Income Mobility in the U. S.', American Economic Review 82, 393-408.

[34] Statistical Abstract of the United States: 2006, U.S. Census Bureau, http://www.census.gov/prod/www/statistical-abstract.html.

[35] Summers, L. (1981). Capital Accumulation and Taxation in a Life-Cycle Growth Model', American Economic Review, 71 (September): 533-44. 